\title{
Ephrin B1 Is Expressed on Neuroepithelial Cells in Correlation with Neocortical Neurogenesis
}

\author{
Ingo Stuckmann, ${ }^{1}$ Anja Weigmann, ${ }^{1}$ Andrej Shevchenko, ${ }^{2}$ Matthias Mann,, ${ }^{2}$ and Wieland B. Huttner ${ }^{1,3}$ \\ ${ }^{1}$ Department of Neurobiology, University of Heidelberg, D-69120 Heidelberg, Germany, ${ }^{2}$ European Molecular Biology \\ Laboratory, D-69012 Heidelberg, Germany, and 3Max-Planck-Institute of Molecular Cell Biology and Genetics, D-01307 \\ Dresden, Germany
}

To identify molecules involved in neurogenesis, we have raised monoclonal antibodies against embryonic day 12.5 mouse telencephalon. One antibody, monoclonal antibody $25 \mathrm{H} 11$, stains predominantly the ventricular zone of the anterior and lateral telencephalon. Purification of the $25 \mathrm{H} 11$ antigen, a $47 \mathrm{kDa}$ integral membrane protein, from $\approx 2500$ mouse telencephali reveals its identity with ephrin B1. Ephrin B1 appears at the onset of neocortical neurogenesis, being first expressed in neuron-generating neuroepithelial cells and rapidly thereafter in virtually all neuroepithelial cells. Expression of ephrin B1 persists through the period of neocortical neurogenesis and is downregulated thereafter. Ephrin B1 is present on the ventricular as well as basolateral plasma membrane of neuroepithelial cells and exhibits an ventricular-high to pial-low gradient across the ventricular zone. Expression of ephrin B1 is also detected on radial glial cells, extending all the way to their pial endfeet, and on neurons in the mantle/intermediate zone but not in the cortical plate. Our results suggest that ephrin B1, presumably via ephrin-Eph receptor signaling, has a role in neurogenesis. Given the ventricular-to-pial gradient of ephrin B1 on the neuroepithelial cell surface and its known role in cell migration in other systems mediated by its repulsive properties, we propose that ephrin B1 may be involved in the migration of newborn neurons out from the ventricular zone toward the neocortex.

Key words: ephrin; neocortex; neurogenesis; neuroepithelial cells; neuronal migration; ventricular zone
Neuroepithelial cells are the precursors to all neurons and macroglial cells of the vertebrate CNS. During development, an increasing proportion of neuroepithelial cells switch, in the specific spatial and temporal patterns of neurogenesis, from proliferative divisions, which produce more neuroepithelial cells, to neuron-generating divisions. The newborn, postmitotic neurons migrate out of the neuroepithelium in the pial direction to form the neuron-containing structures of the brain and spinal cord (Bayer and Altman, 1991; Jacobson, 1991; McConnell, 1995; Rakic, 1995; Caviness et al., 2000).

Two principal types of signaling have been implicated in the control of neurogenesis. One is the signaling by secreted molecules, notably trophic factors, that activate cell surface receptors (Temple and Qian, 1995; Cameron et al., 1998). The other is the signaling via pairs of plasma membrane proteins that are expressed on the cell surface of neighboring cells, with the DeltaNotch system as a paradigm (Campos-Ortega, 1995; ArtavanisTsakonas et al., 1999). However, despite significant progress during the past decade, many components of the signaling machinery involved in the control of neurogenesis remain to be uncovered.

\footnotetext{
Received Aug. 9, 2000; revised Jan. 4, 2001; accepted Jan. 17, 2001.

W.B.H. was supported by grants from the Deutsche Forschungsgemeinschaft (SFB 317, D2), the German-Israeli Foundation for Scientific Research and Development, and the Fonds der Chemischen Industrie. We thank Dr. Rüdiger Klein for the anti-ephrin B antiserum and Andrea Hellwig for immunogold electron microscopy and help with the figures.

Correspondence should be addressed to Wieland B. Huttner, Department of Neurobiology, University of Heidelberg, Im Neuenheimer Feld 364, D-69120 Heidelberg, Germany. E-mail: whuttner@sun0.urz.uni-heidelberg.de.

Dr. Stuckmann's present address: Harvard Medical School, Department of Biological Chemistry and Molecular Pharmacology, 240 Longwood Avenue, Boston, MA 02115.

Copyright (C) 2001 Society for Neuroscience $\quad 0270-6474 / 01 / 212726-12 \$ 15.00 / 0$
}

To identify molecules involved in neurogenesis, we have raised monoclonal antibodies (mAbs) against embryonic day 12.5 (E12.5) mouse telencephali and have focused on one, mAb $25 \mathrm{H} 11$, which stains the neuroepithelium in correlation with neurogenesis. We characterize the cellular and subcellular distribution as well as the temporal expression pattern of the $25 \mathrm{H} 11$ antigen which, after its purification, has been identified as ephrin B1.

\section{MATERIALS AND METHODS}

Monoclonal antibody $25 \mathrm{H11}$

A LouXSD rat was immunized with mouse E12.5 telencephali as described (Weigmann et al., 1997), except that dissociated cells carried through one cycle of freezing and thawing, rather than homogenized tissue, were used as immunogen. For the isolation of mAb 25H11, hybridoma supernatants were screened by light microscopic immunocytochemistry on cryosections of E12.5 mouse brains. Hybridoma clones were grown in DMEM supplemented with either $10 \%$ fetal calf serum or, for the preparation of the $25 \mathrm{H} 11$-Sepharose, $1 \%$ Nutridoma (Boehringer Mannheim, Mannheim, Germany). In the latter case, the 25H11 antibody was concentrated by ammonium sulfate precipitation (50\% saturation). $\mathrm{mAb} 25 \mathrm{H} 11$ is an $\mathrm{IgG}$.

\section{Embryonic brain tissue}

NMRI mice were used. The noon after the morning when the vaginal plug was detected was defined as E0.5. Embryos were staged according to Theiler (1989). Specifically, E9.5 embryos had turned, had 21-29 somites, the anterior neural tube was closed, and forelimb buds were present; E10.0 embryos were at least twice as big as E9.5 embryos, had first signs of red blood cells in the circulation and of olfactory pits, and hindlimb buds were present; E10.5 embryos were further developed than E10.0 embryos with regard to the vascular system and the size of the hindlimb buds, and had a pronounced olfactory pit; stages later than E10.5 were assessed by overall size and, particularly, by limb and digit development.

Whole brains and telencephali (as specified below and in the figure legends) were dissected on ice in (in $\mathrm{mM}$ ): $150 \mathrm{NaCl}, 5.4 \mathrm{KCl}, 2 \mathrm{CaCl}_{2}$, $1 \mathrm{MgCl}_{2}$, and 5 HEPES-NaOH, pH 7.4. For the purification of the $25 \mathrm{H} 11$ antigen, telencephali were dissected in PBS. For $\beta$ III-tubulin 

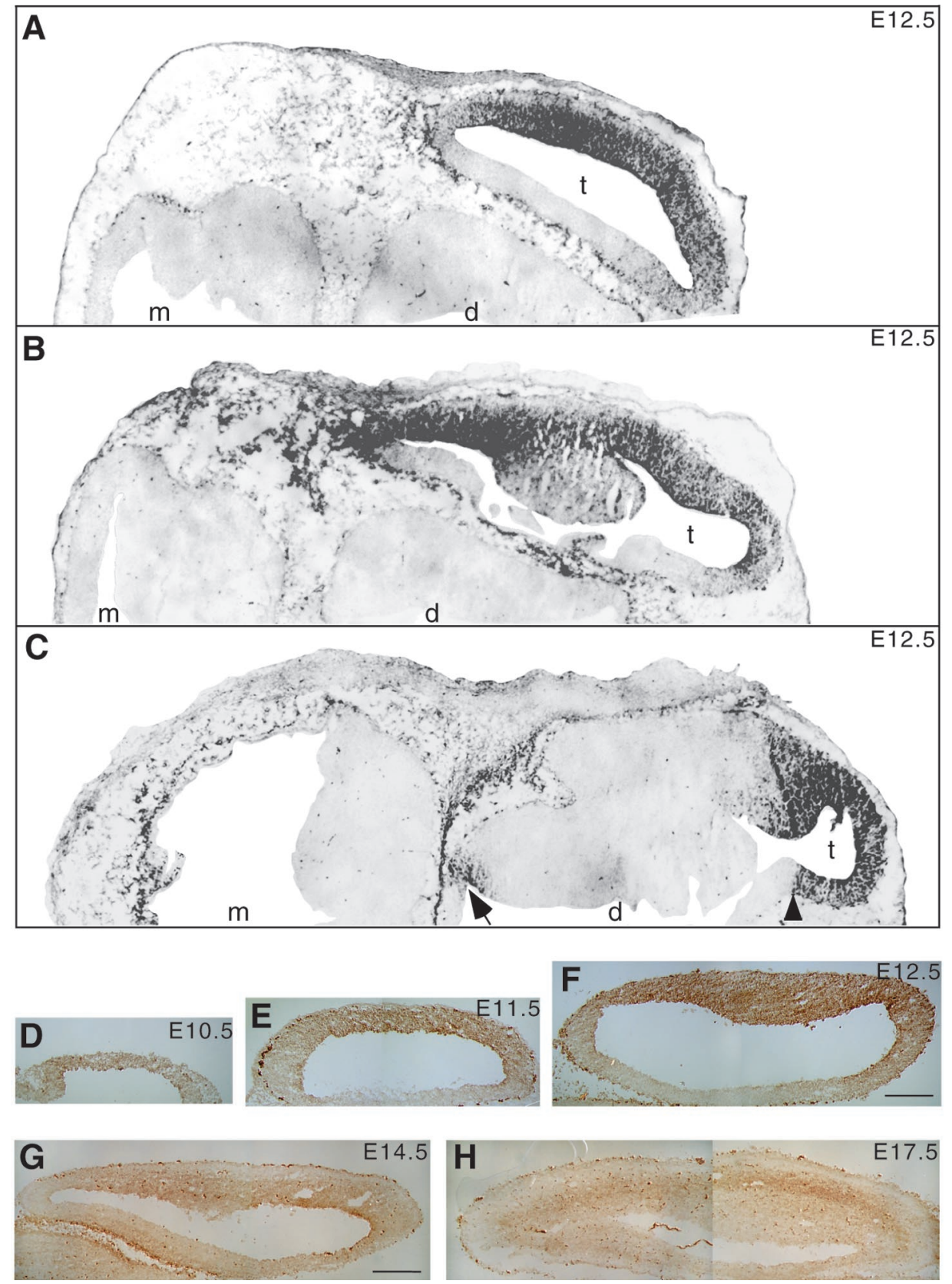

Figure 1. $25 \mathrm{H} 11$ immunoreactivity in the embryonic mouse brain. Immunoperoxidase staining $(A-C$, black $; D-H$, brown $)$ using mAb $25 \mathrm{H} 11$ on cryosections of embryonic mouse brain. $A-C$, E12.5, transverse sections at dorsal $(A)$, intermediate $(B)$, and ventral $(C)$ level; to allow presentation at higher magnification (same for $A-C$ ), only one half of each section is shown. Note the immunostaining in the telencephalon $(t)$, which is much stronger laterally than medially; an apparent boundary of immunostaining in the medial telencephalon is indicated by the arrowhead in $C$. Diencephalon $(d)$ and mesencephalon $(m)$ lack 25H11 immunostaining, except for a region that will give rise to the hypothalamus $(C$, arrow $)$. Outside the brain, mesenchymal cells are immunoreactive. Staining of the choroid plexus and of scattered cells in the diencephalon and mesencephalon was also seen in sections carried through the peroxidase reaction without previous incubation with primary and secondary antibodies (data not shown), and hence reflects endogenous peroxidase activity. $D-H$, Transverse sections of telencephalic vesicles at E10.5 $(D)$, E11.5 $(E)$, E12.5 $(F)$, E14.5 $(G)$, and E17.5 $(H)$. Anterior is to the right of each panel. The strongly stained cells contain endogenous peroxidase activity (see also Fig. $6 F$ ). Magnifications are the same for $D-F$ and for $G$ and $H$. Scale bars: $F, 100 \mu \mathrm{m}$; $G, 200 \mu \mathrm{m}$. immunofluorescence, brains were dissected at room temperature. For immunocytochemistry, the tissue was fixed as described below. For the purification of the $25 \mathrm{H} 11$ antigen and for biochemical analyses, telencephali were homogenized (see below) or frozen in liquid nitrogen. The frozen telencephali of various embryonic stages were thawed by the addition of $1 \%(\mathrm{w} / \mathrm{v})$ SDS $(\approx 1 \mathrm{ml} / \mathrm{mg}$ protein $)$ and solubilized by several passes through a needle $(0.55 \times 25 \mathrm{~mm} / 24$ gauge $\times 1$ inch $)$ attached to a $1 \mathrm{ml}$ syringe followed by heating for $5 \mathrm{~min}$ to $95^{\circ} \mathrm{C}$.

\section{Light microscopic immunocytochemistry}

Tissue was immersed in ice-cold fixative containing $2 \%$ paraformaldehyde, $4 \%$ sucrose, $2 \mathrm{mM} \mathrm{CaCl}_{2}$, and $200 \mathrm{~mm}$ HEPES-NaOH, pH 7.4, allowed to reach room temperature for $30 \mathrm{~min}$, and kept in fixative at $4^{\circ} \mathrm{C}$ overnight. The fixed tissue was infiltrated with sucrose, frozen in Tissuetek, and $14 \mu \mathrm{m}$ (Fig. 1;8 $\mu \mathrm{m}$ ) cryosections were prepared and processed as described (Aaku-Saraste et al., 1997), except that the sections were collected on TESPA-coated rather than gelatin-coated glass slides, and the blocking medium contained $3 \%$ fetal calf serum instead of $0.05 \%$ BSA. In the case of immunoperoxidase staining, the endogenous peroxidase was not quenched with $\mathrm{H}_{2} \mathrm{O}_{2}$ because this treatment resulted in massive reduction in $25 \mathrm{H} 11$ staining. Sections were incubated with the primary antibody (in the case of double immunofluorescence with a mixture of two primary antibodies) for $2 \mathrm{hr}$ at room temperature in blocking medium (except for the immunoperoxidase stainings shown in Figs. $1 D-H, 6 E, F)$. The primary antibodies used and their dilution and concentration were as follows: rat mAb $25 \mathrm{H} 11$, hybridoma supernatant $1: 6(\approx 4 \mu \mathrm{g} / \mathrm{ml})$; affinity-purified rabbit K4 antibody against mouse TIS21 (Iacopetti et al., 1999) $0.5 \mu \mathrm{g} / \mathrm{ml}$; mouse mAb against $\beta$ III-tubulin (Sigma, St. Louis, MO; T-8660) $8 \mu \mathrm{g} / \mathrm{ml}$, rabbit antiserum against nestin (a kind gift of Dr. E. Aaku-Saraste) 1:10; rabbit antiserum against the C terminus of ephrin B (anti-Lerk2A; a kind gift from Dr. R. Klein) (Brückner et al., 1997) 1:10; rabbit antiserum against ephrin B2 [Santa Cruz Biotechnology, Santa Cruz, CA; (P-20): sc-1010] 1:100; and rabbit antiserum against ephrin B3 [Santa Cruz Biotechnology (G-15): sc-9934] 1:100. After washing, sections were incubated for $1 \mathrm{hr}$ with the secondary antibody (in the case of double immunofluorescence with a mixture of two secondary antibodies) in blocking medium: peroxidase-coupled goat anti-rat 1:300 (Fig. 1A-C only), tetramethylthodamine isothiocyanate (TRITC)-conjugated goat anti-rabbit 1:200, fluorescein dichlorotriazine (DTAF)-conjugated goat anti-rat 1:200, rhodamine-conjugated rabbit 
A

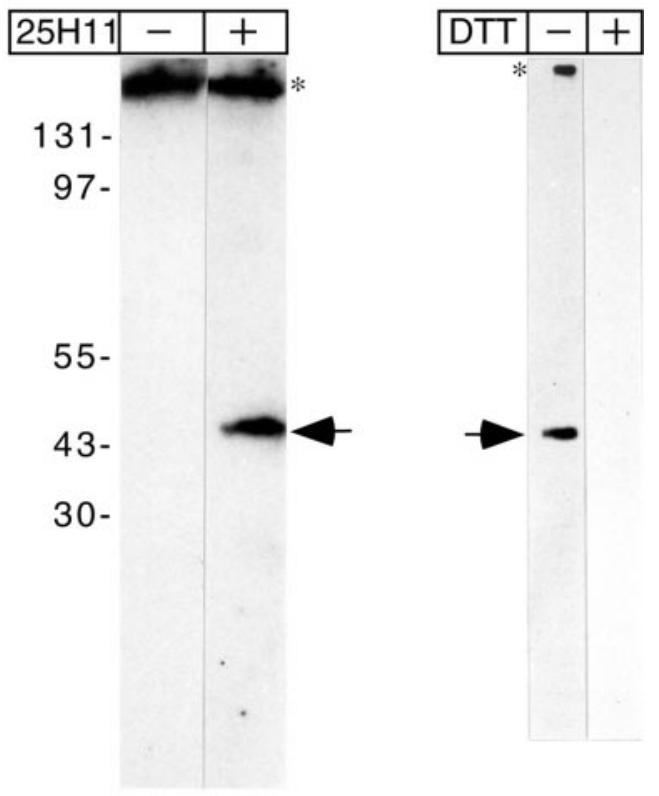

C Fraction

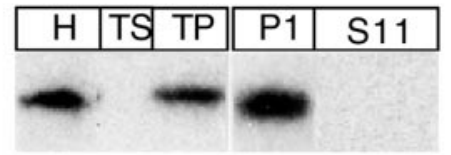

D Sucrose (M)

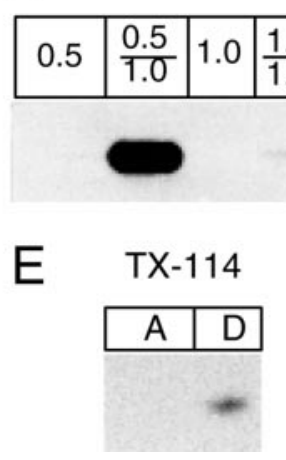

Figure 2. The $25 \mathrm{H} 11$ antigen is a $47 \mathrm{kDa}$ integral membrane protein. $A$, Immunoblot after nonreducing SDS-PAGE of the total homogenate of $\approx 1.7$ mouse E12.5 telencephali without $(-)$ and with $(+) 25 \mathrm{H} 11$ antibody followed by $\left[{ }^{125} \mathrm{I}\right]$ Protein A. B, After nonreducing SDS-PAGE of the total homogenate of $\approx 0.7$ mouse E13.5 telencephali, nitrocellulose filters were treated without $(-)$ and with $(+) 10 \mathrm{~mm}$ DTT at $55^{\circ} \mathrm{C}$, followed by immunolabeling with $25 \mathrm{H} 11$ antibody and the ECL detection system. $A$, $B$, Arrows, 25H11 antigen; asterisks, endogenous protein (presumably mouse $\mathrm{Ig}$ ) recognized by the secondary antibody. The positions of molecular weight markers are indicated in $A$. $C, 25 \mathrm{H} 11$ Immunoblots of various fractions prepared from the homogenate of $\approx 3$ E12-E13 mouse telencephali. Left immunoblot, $H$, homogenate; TS, total supernatant; TP, total pellet. Right immunoblot, P11 and S11, pellet and supernatant, respectively, obtained from the total pellet by $\mathrm{pH} 11$ carbonate treatment. $D, 25 \mathrm{H} 11$ immunoblot of fractions from a floatation sucrose step gradient of $\mathrm{pH} 11$ carbonate-treated membranes prepared from seven E13.5 mouse telencephali. The entire $0.5,1.0$, and $1.5 \mathrm{M}$ sucrose phases and the two interfaces were analyzed. Pel, Pellet. E, 25H11 immunoblot of the aqueous (lane $A$ ) and detergent (lane $D$ ) phase obtained after phase condensation of a Triton X-114 extract of pH 11 carbonate-treated membranes prepared from $\approx 1$ E13.5 mouse telencephalon. anti-rat 1:300, Cy2-conjugated goat anti-mouse 1:100, Сy2-conjugated goat anti-rabbit 1:100, and Cy3-conjugated goat anti-rat 1:200 (all from Dianova, Hamburg, Germany). In the case of the immunoperoxidase staining shown in Figure $1 A-C$, the color reaction was performed for $\approx 10 \mathrm{~min}$ with $\mathrm{DAB}(0.5 \mathrm{mg} / \mathrm{ml})$ in $\mathrm{PBS}$ containing $0.01 \% \mathrm{H}_{2} \mathrm{O}_{2}$. In the case of the immunoperoxidase stainings shown in Figures $1 D-H$ and 6 , $E$ and $F$, the Vectastain ABC kit (Vector Laboratories, Burlingame, CA) was used according to the instructions of the manufacturer. The sections were mounted with Moviol and observed with a Zeiss Axiophot microscope. Fluorescein bleaching was performed by illuminating the section for $\approx 3$ min using the appropriate filter.

Cell surface immunofluorescence of intact neuroepithelial cells For cell surface immunofluorescence, all steps before fixation were performed at $4^{\circ} \mathrm{C}$. Isolated E11.5 telencephali were incubated for $6 \mathrm{hr}$ in incubation medium (in mM: $150 \mathrm{NaCl}, 5.4 \mathrm{KCl}, 2 \mathrm{CaCl}_{2}, 1 \mathrm{MgCl}_{2}$, and 5 HEPES-NaOH, pH 7.4, supplemented with $3 \%$ FCS) either mixed with 0.25 volumes of $25 \mathrm{H} 11$ hybridoma supernatant or containing the rabbit antiserum against the C-terminal 52 amino acids of prominin (Weigmann et al., 1997) at 1:3000 dilution. After five washes over a $2 \mathrm{hr}$ period with incubation medium, the tissue was incubated for 45 min with appropriate secondary antibody (TRITC-conjugated goat anti-rat 1:300 and TRITC-conjugated goat anti-rabbit 1:200) diluted in incubation medium, followed by five washes over a $1 \mathrm{hr}$ period. The tissue was fixed with $2 \%$ paraformaldehyde, and cryosections were prepared and observed as described above.

\section{Immunogold electron microscopy}

Immunogold electron microscopy of ultrathin cryosections was performed as described (Aaku-Saraste et al., 1996, 1997), using undiluted $25 \mathrm{H} 11$ hybridoma supernatant followed by a rabbit anti-rat bridge antibody (1:30) and 14 or $9 \mathrm{~nm}$ protein A-gold.

\section{Purification of the $25 H 11$ antigen}

Preparation of carbonate-treated membranes. All steps were performed at $4^{\circ} \mathrm{C}$. E13.5 mouse telencephali (100-500 for each preparation) were homogenized in 20 volumes of $0.3 \mathrm{~m}$ sucrose, $10 \mathrm{~mm}$ HEPES-NaOH, $\mathrm{pH}$ 7.4 , using a glass-Teflon homogenizer ( 5 strokes at $1000 \mathrm{rpm}$ followed by 10 strokes at $2000 \mathrm{rpm}$ ). The homogenate was centrifuged for $15 \mathrm{~min}$ at $1000 \times g$, and the resulting supernatant was centrifuged for $30 \mathrm{~min}$ at $200,000 \times g$. The $200,000 \times g$ pellet was resuspended in twice the original volume of $0.1 \mathrm{M} \mathrm{Na}_{2} \mathrm{CO}_{3}, \mathrm{pH} 11$, containing $1 \mathrm{mg} / \mathrm{ml}$ saponin, and centrifuged for $30 \mathrm{~min}$ at $200,000 \times g$. The resulting pellet $(\mathrm{P} 11)$, referred to as carbonate-treated membranes, was resuspended in a minimal volume of PBS, adjusted to neutral $\mathrm{pH}$, and stored at $-80^{\circ} \mathrm{C}$.

Preparation of 25H11-Sepharose. All steps were performed at $4^{\circ} \mathrm{C}$. Ammonium sulfate-precipitated mAb 25H11 was dissolved in, and dialyzed against, PBS, and cleared by ultracentrifugation. After dialysis against $0.1 \mathrm{~m} \mathrm{NaHCO}_{3} \mathrm{pH} 8.3,0.5 \mathrm{~m} \mathrm{NaCl}, 10 \mathrm{ml}$ of the mAb 25H11 solution $(4 \mathrm{mg} / \mathrm{ml})$ was coupled with $10 \mathrm{ml}$ of cyauogen bromide $(\mathrm{BrCN})$ activated Sepharose 4B (1.5 gm in $0.1 \mathrm{M} \mathrm{NaHCO}_{3} \mathrm{pH} 8.3,0.5 \mathrm{M} \mathrm{NaCl}$; Amersham Pharmacia Biotech, Braunschweig, Germany) overnight at $4^{\circ} \mathrm{C}$. $25 \mathrm{H} 11$-Sepharose was quenched with $0.1 \mathrm{M}$ glycine, $\mathrm{pH} 8.5,0.1 \mathrm{M}$ $\mathrm{NaCl}$ overnight at $4^{\circ} \mathrm{C}$, washed, and stored in PBS containing $0.05 \%$ $\mathrm{NaN}_{3}$. The coupling efficiency was $\approx 63 \%$.

Solubilization. All steps were performed at $4^{\circ} \mathrm{C}$. Carbonate-treated membranes from $\approx 2500$ telencephali were thawed by the addition of buffer A [in mM: $150 \mathrm{NaCl}, 10$ EDTA, $1 \%$ (w/v) Triton X-100, and 50 Tris-HCl, $\mathrm{pH}$ 7.8, $15 \mu \mathrm{l}$ per membranes from one telencephalon], and the Triton X-100 lysate was incubated for $1 \mathrm{hr}$ on a rocker. Insoluble material was removed by centrifugation $(200,000 \times g, 30 \mathrm{~min})$; the supernatant is referred to as Triton X-100 extract.

Immunoaffinity isolation. Immunoaffinity isolation was performed batch-wise at $20^{\circ} \mathrm{C}$. The Triton X-100 extract was incubated with $25 \mathrm{H} 11-$ Sepharose $(1 \mu$ l beads extract from one telencephalon) for $1 \mathrm{hr}$ on a rocker, washed extensively with buffer $\mathrm{A}$ and then with buffer A containing $40 \mathrm{~mm}$ octylglucoside instead of Triton X-100, and eluted with (in mM) $150 \mathrm{NaCl}, 40$ octylglucoside, and 50 glycine-HCl, $\mathrm{pH} 2.5$, followed by immediate neutralization with $1 \mathrm{~N} \mathrm{NaOH}$. Multiple rounds of adsorption to the $25 \mathrm{H} 11$-Sepharose and elution were required to recover the bulk of the $25 \mathrm{H} 11$ antigen present in the Triton X-100 extract, as monitored by immunoblotting (see below). The $25 \mathrm{H} 11$ antigen present in the eluate is referred to as immunoaffinity-isolated $25 \mathrm{H} 11$ antigen.

Preparative SDS-PAGE. Immunoaffinity-isolated $25 \mathrm{H} 11$ antigen $(\approx 45$ $\mathrm{ml}$ ) was precipitated by the addition of 12 volumes of $-25^{\circ} \mathrm{C}$ acetone and 
A

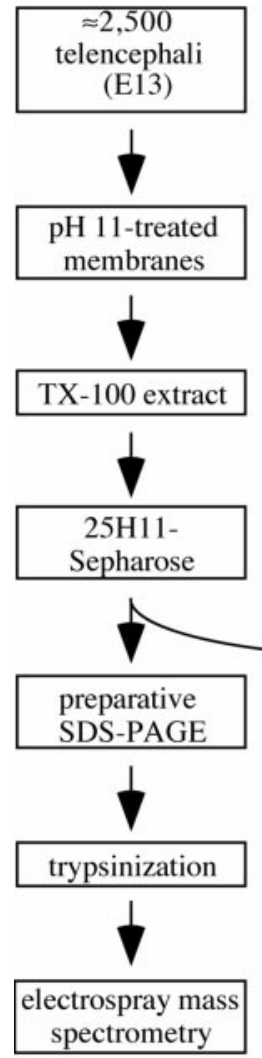

B

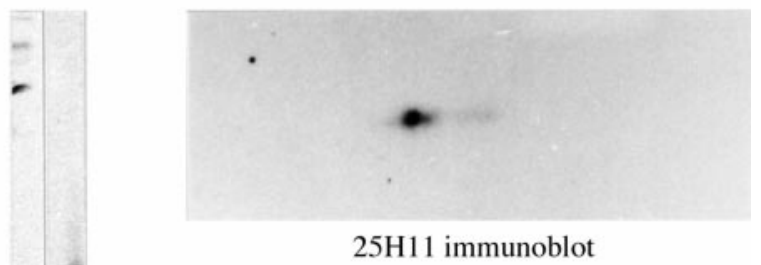

Figure 3. Purification of the $25 \mathrm{H} 11$ antigen. A, Flow scheme of the purification of the $25 \mathrm{H} 11$ antigen from E13.5 mouse telencephali and of its further processing for nanosequencing. For details, see Materials and Methods. $B$, Aliquots $(0.2 \%)$ of the eluate from the 25H11-Sepharose $(A)$ were analyzed by SDS-PAGE followed by silver staining or were biotinylated and analyzed by SDS-PAGE followed by streptavidin blotting. Arrow, 25H11 antigen. $C, C^{\prime}$, The $25 \mathrm{H} 11$ antigen was purified through the $25 \mathrm{H} 11$-Sepharose step as described in $A$, except that only $\approx 140$ E13.5 mouse telencephali were used. An aliquot $(25 \%)$ of the eluate from the 25H11-Sepharose was PEG-precipitated and biotinylated, and an aliquot of it $(80 \%)$ was analyzed by two-dimensional PAGE (acidic, right) followed by immunoblotting with the $25 \mathrm{H} 11$ antibody $(C$, $\approx 5$ min time $\mathrm{ECL}$ exposure). The nitrocellulose was incubated in reducing condition to remove the antibody and reprobed with streptavidin-HRP $\left(C^{\prime}\right.$, $\approx 1$ min time ECL exposure).

kept at $-25^{\circ} \mathrm{C}$ overnight. The precipitate was collected by centrif ugation at $4^{\circ} \mathrm{C}$ for $2 \mathrm{hr}$ at $150,000 \times g$, solubilized in $5 \mathrm{ml}$ of $1 \%(\mathrm{w} / \mathrm{v}) \mathrm{SDS}, 20 \mathrm{~mm}$ Tris-HCl, pH 6.8, and equilibrated with this buffer and reduced to $2 \mathrm{ml}$ by repeated rounds of ultrafiltration using Centricon 4206 (Amicon, Beverly, MA). The sample was made up to $6 \%$ (w/v) SDS, $62.5 \mathrm{~mm}$ Tris- $\mathrm{HCl}, \mathrm{pH} 6.8$, heated to $56^{\circ} \mathrm{C}$ for $10 \mathrm{~min}$, cleared of insoluble material by centrifugation for $2 \mathrm{~min}$ at $10,000 \times g$, and subjected to preparative SDS-PAGE under nonreducing conditions using a 1-mmthick $10 \%$ gel with a $3-\mathrm{cm}$-wide slot. After electrophoresis, the gel was silver-stained as described (Shevchenko et al., 1996), except for a thin stripe that was subjected to immunoblotting to verify the identity of the major bands as the monomer and homodimer of the $25 \mathrm{H} 11$ antigen. These bands were cut out from the gel and subjected to microsequence analysis.

\section{Nanoelectrospray tandem mass spectrometry}

The excised band was in-gel-digested with trypsin (Boehringer Mannheim; unmodified, sequencing grade) as described (Shevchenko et al., 1996). The unseparated pool of tryptic peptides was sequenced by nanoelectrospray tandem mass spectrometry as described (Wilm et al., 1996a,b). Sequencing was performed on an API III triple quadrupole mass spectrometer (PE Sciex, Ontario, Canada). Peptide sequence tags were assembled using tandem mass spectrometric data (Mann and Wilm, 1994). Comprehensive protein databases were searched with PeptideSearch version 3.0 software.

\section{Analytical procedures}

Some of the procedures described under "Purification of the 25H11 antigen" were also applied at the analytical scale, with minor modifications as described below.

Carbonate-treated membranes. For Figure $8 A$, the homogenate was directly centrifuged at $200,000 \times g$ to yield a total supernatant and pellet, with carbonate-treated membranes being prepared from the latter.

Immunoaffinity isolation. The Triton X-100 lysate was incubated with $\approx 5 \mu \mathrm{l} 25 \mathrm{H} 11$-Sepharose beads per lysate from one telencephalon and eluted with $150 \mathrm{~mm} \mathrm{NaCl}, 1 \%$ Triton X-100, and $50 \mathrm{~mm}$ glycine- $\mathrm{HCl}, \mathrm{pH}$ 2.5. In some experiments, Sepharose beads containing covalently coupled control Ig rather than 25H11-Sepharose were used. The control Igs were obtained from rat serum by ammonium sulfate precipitation (50\% saturation) followed by DEAE ion exchange chromatography, and $100 \mu \mathrm{l}(6$ $\mathrm{mg}$ protein per $\mathrm{ml}$ ) were coupled with $200 \mu \mathrm{l}$ of BrCN-activated Sepharose $4 \mathrm{~B}$, as described above for $25 \mathrm{H} 11-$ Sepharose.

\section{Membrane floatation}

All steps were performed at $4^{\circ} \mathrm{C}$. Carbonate-treated membranes were resuspended in $1.5 \mathrm{M}$ sucrose and $0.1 \mathrm{M} \mathrm{Na}_{2} \mathrm{CO}_{3} \mathrm{pH} 11$, overlaid with a sucrose step gradient $\left(1.0\right.$ and $0.5 \mathrm{M}$ sucrose in $0.1 \mathrm{M} \mathrm{Na}_{2} \mathrm{CO}_{3}, 1.5 \mathrm{ml}$ each) and centrifuged at $200,000 \times g$ for $3 \mathrm{hr}$ at $4^{\circ} \mathrm{C}$. Phases, interfaces, and the pellet were collected, diluted at least threefold with $0.1 \mathrm{M}$ $\mathrm{Na}_{2} \mathrm{CO}_{3}$, centrifuged for $40 \mathrm{~min}$ at $100,000 \times \mathrm{g}$, and the pellets were analyzed by immunoblotting.

\section{Triton $X$-114 phase condensation}

Carbonate-treated membranes were solubilized at $4^{\circ} \mathrm{C}$ in $\approx 150 \mu \mathrm{l}$ per telencephalon of $1 \%(\mathrm{w} / \mathrm{v})$ Triton X-114, $150 \mathrm{~mm} \mathrm{NaCl}$, and $30 \mathrm{~mm}$ sodium phosphate buffer, $\mathrm{pH}$ 7.6. Phase condensation (Bordier, 1981) was performed for $5 \mathrm{~min}$ at $37^{\circ} \mathrm{C}$ followed by centrifugation at $10,000 \times$ $g$ for $5 \mathrm{~min}$ at room temperature. The entire aqueous and detergent phase were analyzed by immunoblotting.

\section{Polyethylene glycol precipitation}

Immunoaffinity-isolated $25 \mathrm{H} 11$ antigen was mixed with polyethylene glycol (20,000 PEG; Serva 33138) in PBS to a final concentration of 30\% $(\mathrm{w} / \mathrm{v})$, kept for $1 \mathrm{hr}$ on ice, centrifuged at $18,000 \times g$ for $15 \mathrm{~min}$, and the pellet was used further.

\section{Biotinylation}

Immunoaffinity-isolated $25 \mathrm{H} 11$ antigen precipitated with either acetone or polyethylene glycol was solubilized in $130 \mathrm{~mm} \mathrm{NaCl}$ and $30 \mathrm{~mm}$ Bicine, $\mathrm{pH}$ 7.4, containing $1 \mathrm{~mm}$ sulfo-NHS-biotin (Pierce, Rockford, IL). Immunoaffinity-isolated $25 \mathrm{H} 11$ antigen not precipitated with acetone or polyethylene glycol was mixed with 2.7 volumes of the same buffer except that sulfo-NHS-biotin was increased to a final concentration of $20 \mathrm{~mm}$. 


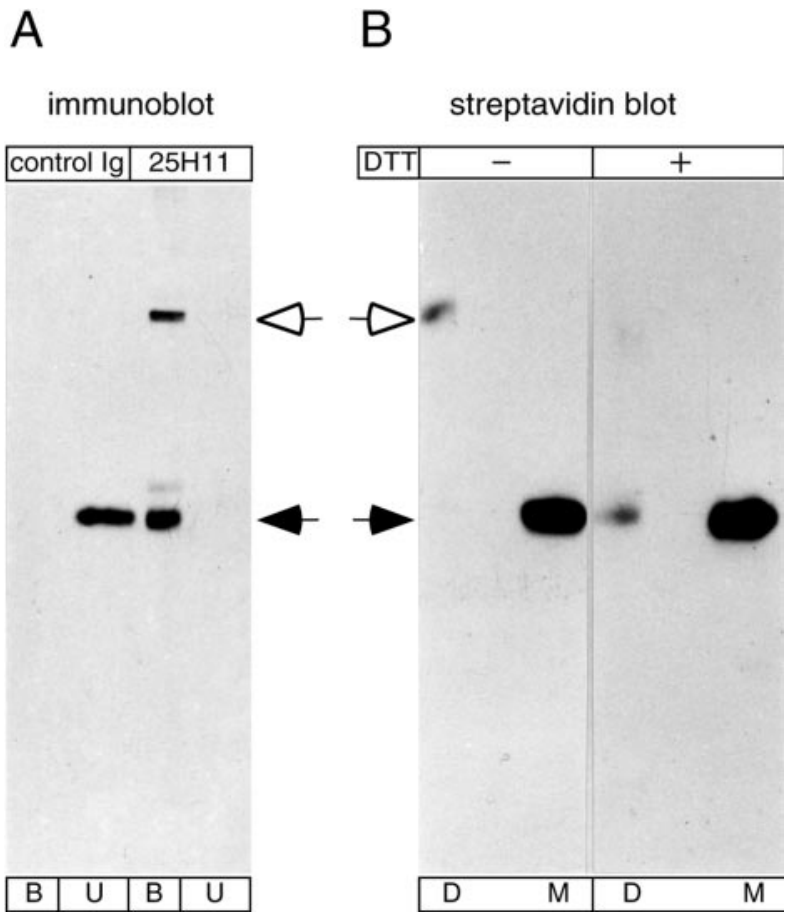

Figure 4. Disulfide-mediated homodimerization of the $25 \mathrm{H} 11$ antigen during immunoaffinity isolation. $A$, Aliquots of a Triton X-100 lysate obtained from 10 E13.5 mouse telencephali as described in Figure $11 \mathrm{~A}$ were incubated with $25 \mathrm{H} 11$-Sepharose $(25 \mathrm{H} 11)$ or Sepharose conjugated with normal rat Igs (control $\mathrm{Ig}$ ), followed by $25 \mathrm{H} 11$ immunoblot analysis of the unbound proteins $(U)$ and the bound proteins eluted from the Sepharose $(B)$. B, The $25 \mathrm{H} 11$ antigen was purified through the $25 \mathrm{H} 11$ Sepharose step as described in Figure $11 A$, except that the Triton X-100 lysate of only $\approx 55$ E13.5 mouse telencephali was used. An aliquot of the eluate from the 25H11-Sepharose was biotinylated and subjected to SDSPAGE under nonreducing conditions, and the positions of biotinylated proteins in the gel were determined by streptavidin blotting of thin stripes of the gel. Gel pieces containing either the dimer $(D)$ or monomer $(M)$ of the $25 \mathrm{H} 11$ antigen were treated without $(-)$ or with $(+)$ DTT followed by SDS-PAGE and streptavidin blotting. To facilitate comparison, the exposure shown for the reduced samples is longer than that shown for the nonreduced samples. A, B, Open arrows, dimer, and filled arrows, monomer, of the $25 \mathrm{H} 11$ antigen.

After incubation for either $2 \mathrm{hr}$ at $4^{\circ} \mathrm{C}$ or $30 \mathrm{~min}$ at room temperature, and the biotinylation reaction was stopped by the addition of $1 / 10$ volume of $1 \mathrm{~m}$ glycine, followed by SDS-PAGE or two-dimensional PAGE and streptavidin blotting (see below).

\section{SDS-PAGE and two-dimensional gel analysis}

SDS-PAGE was performed using $10 \%$ resolving gels. Two-dimensional PAGE was performed using isoelectric focusing [3.5\% (v/v), $\mathrm{pH} 3.5-9.0$; $1.75 \%(\mathrm{v} / \mathrm{v}), \mathrm{pH} 5.0-7.0$; and $1.75 \%$ (v/v), $\mathrm{pH} 7.0-9.0$ ampholyte solution containing in each case $40 \%$ (w/v) ampholytes; Amersham Pharmacia Biotech, Uppsala, Sweden] in the first dimension and 10\% resolving gels in the second dimension. Unless otherwise indicated, both SDS-

family members ( $\alpha$-ephrin B). Open arrow, Dimer of the 25H11 antigen; filled arrow, monomer. Note that the immunoreactivity of the dimer band is less for mAb $25 \mathrm{H} 11$ as compared with $\alpha$-ephrin B because of unequal cutting of the nitrocellulose. $C, C^{\prime}, \mathrm{pH} 11$ carbonate-treated membranes prepared from four E13.5 mouse telencephali were analyzed by twodimensional PAGE (acidic, right) followed by immunoblotting with the $25 \mathrm{H} 11$ antibody $(C, \approx 5 \mathrm{~min}$ time ECL exposure). The nitrocellulose was incubated in reducing condition to remove the antibody and reprobed with an antiserum against the ephrin B family members $\left(C^{\prime}, \approx 1\right.$ min time ECL exposure).
A

Peptide 1

Ephrin B1 V SW S S L N P K

V S W S S IL N P K

Ephrin B2 I $Y$ W $N$ N $S$ S N S K

Ephrin B3 V Y Y W N S S A N K R

Peptide 2 ILG D K IL D ILIL C P R

Ephrin B1 I G D K L D I I C P R

Ephrin B2 I G DKL D I I C P K

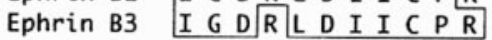

Peptide 3 A A A IL S IL S T IL A S P K

Ephrin B1 A A A L S L S T L A S P K

Ephrin B2 T T T L S L S T L A T P K

Ephrin B3 G G SLL L G G - - - G

Peptide $4 \quad$ G G S G T A G T E P S D IL IL IL P IL R Ephrin B1 G G S G T A G T E P S D I I I P L R Ephrin B2 RG GN N NGSE P S DV I I P L R Ephrin B3 G G M G P R E A E P G E L G I A L R
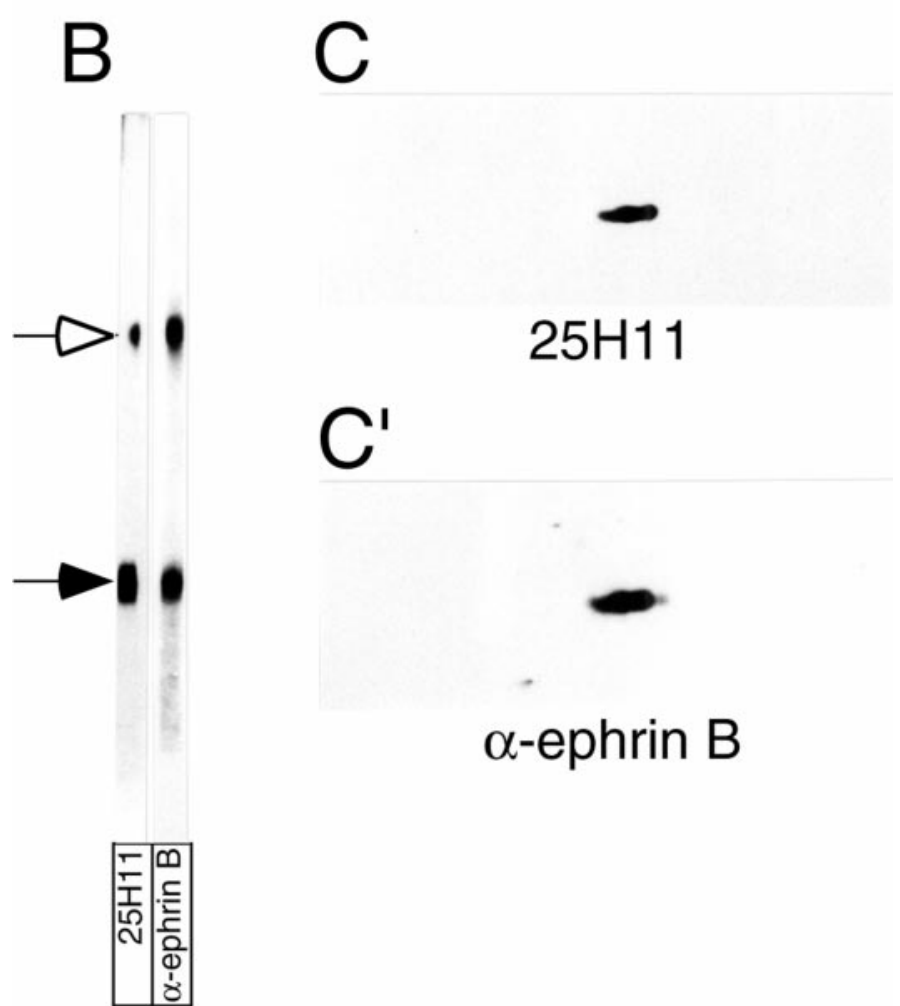

Figure 5. Identification of the $25 \mathrm{H} 11$ antigen as ephrin B1. $A$, The $25 \mathrm{H} 11$ antigen was purified as described in Figure $3 A$, and digested with trypsin, and the sequence of four peptides was determined by nanoelectrospray mass spectrometry. The sequences are shown compared with the corresponding sequences of the members of the mouse ephrin B family; numbers refer to the sequences including the signal peptides. Identical amino acid residues are boxed; leucine $(L)$ and isoleucine $(I)$, which could not be distinguished by mass spectrometry, were equally considered in the comparison of peptides 1-4 with the ephrin B family members $(I L)$. Peptides 1-4 were obtained from the $47 \mathrm{kDa}$ monomer of the $25 \mathrm{H} 11$ antigen; peptides 3 and 4 were independently obtained from the dimer of the $25 \mathrm{H} 11$ antigen. Note that peptides $2-4$ match to predicted internal tryptic peptides of ephrin B1, whereas peptide 1 corresponds to the $\mathrm{C}$-terminal portion of the predicted $\mathrm{N}$-terminal tryptic peptide of mature ephrin B1. B, The $25 \mathrm{H} 11$ antigen was purified through the $25 \mathrm{H} 11$ Sepharose step as described in Figure $3 A$, except that the Triton X-100 lysate of only $\approx 10$ E13.5 mouse telencephali was used. An aliquot of the eluate from the 25H11-Sepharose was subjected to SDS-PAGE followed by transfer to nitrocellulose, which was cut into two stripes and immunolabeled using mAb $25 \mathrm{H} 11$ (25H11) or an antiserum against the ephrin B 

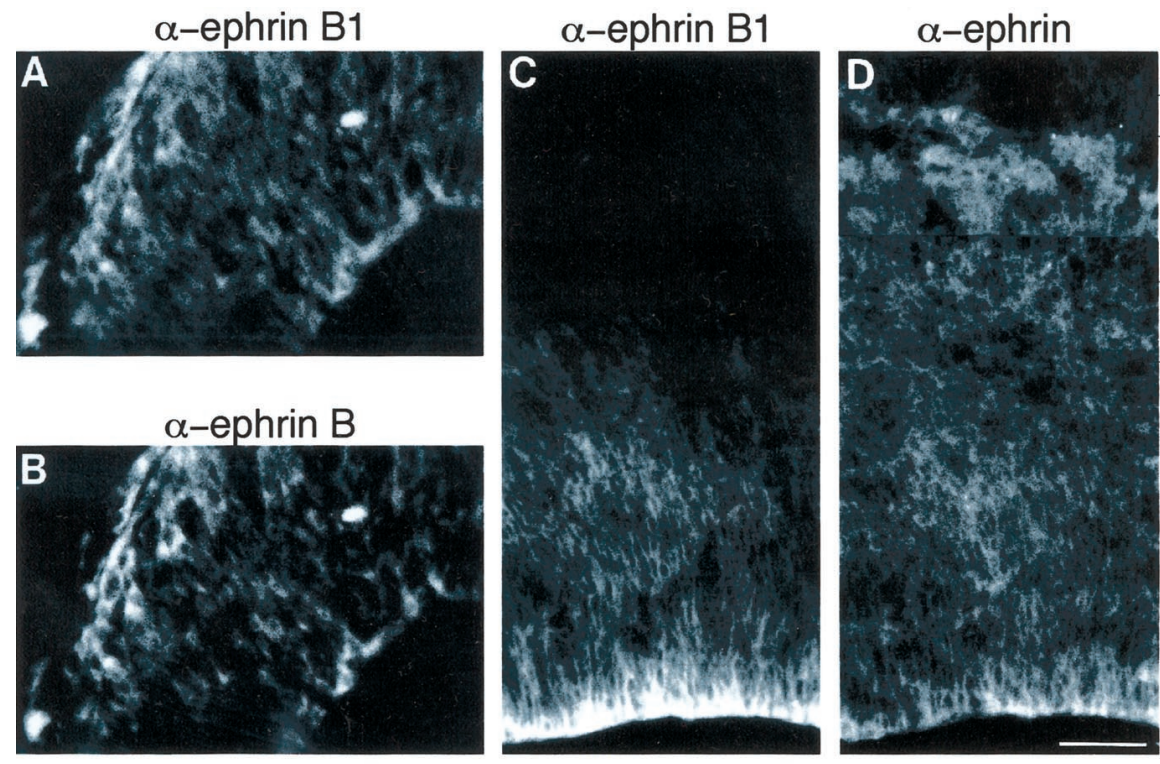

$\bar{M} \bar{Z}$

CP

IZ

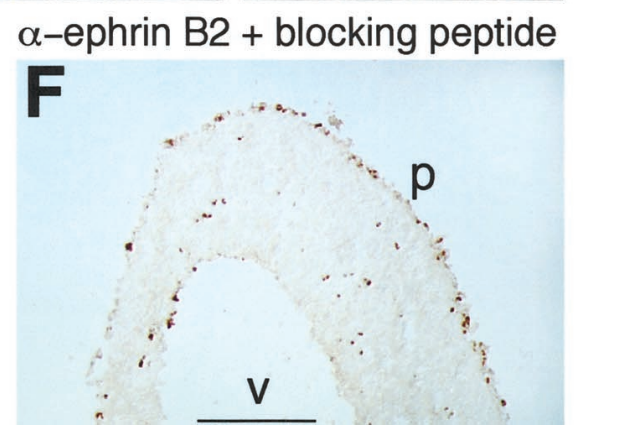

Figure 6. Comparison of the expression pattern of ephrin B1 and other ephrin B family members in the embryonic mouse neocortex. $A-D$, Double immunofluorescence of transverse cryosections of the $\mathrm{E} 10.5(A, B)$ and E14.5 $(C, D)$ mouse telencephalon using mAb $25 \mathrm{H} 11$ against ephrin $\mathrm{B} 1(A, C)$ and $\alpha$-ephrin $\mathrm{B}$ antiserum $(B, D) . V Z$, Ventricular zone; $I Z$, intermediate zone; $C P$, cortical plate; $M Z$, marginal zone. The ventricular side of the neuroepithelium is to the bottom right in $A$ and $B$ and down in $C$ and $D$. All panels are the same magnification. Scale bar: $D, 60 \mu \mathrm{m}$. $E, F$, Immunoperoxidase staining of transverse cryosections of E14.5 mouse telencephalon using $\alpha$-ephrin B2 antiserum without $(E)$ and with $(F)$ previous incubation in the presence of a peptide blocking antibody-ephrin B2 binding. Note the scattered cells in $F$ that exhibit endogenous peroxidase activity. $v$, Ventricular surface; $p$, pial surface. Both panels are the same magnification. Scale bar: $F, 220 \mu \mathrm{m}$.
PAGEand two-dimensional PAGE were performed under nonreducing conditions. Gels were silver-stained according to standard procedures.

\section{Reduction of 25 H11 antigen}

After non-reducing SDS-PAGE of biotinylated 25H11 antigen, the position of the $25 \mathrm{H} 11$ antigen in the gel was determined by immunoblotting of a thin stripe of the gel. Pieces containing biotinylated 25H11 antigen were then excised from the remainder of the gel and incubated for $20 \mathrm{~min}$ at room temperature in three volumes of $3 \%(\mathrm{w} / \mathrm{v})$ SDS, $10 \%(\mathrm{w} / \mathrm{v})$ sucrose, $62.5 \mathrm{~mm}$ Tris-HCl, $\mathrm{pH}$ 6.8, in the absence or presence of $10 \mathrm{~mm}$ DTT followed by boiling for $10 \mathrm{~min}$. Samples were then subjected to SDS-PAGE followed by streptavidin blotting.

\section{Immunoblotting and streptavidin blotting}

Immunoblotting. Immunoblotting toward the anode was performed at 20 $\mathrm{V}$ for $105 \mathrm{~min}$ using $25 \mathrm{~mm}$ Tris, $190 \mathrm{~mm}$ glycine, and $20 \%$ methanol as transfer buffer; however, the electrodes of the blotting apparatus $(\mathrm{Ge}-$ nieblotter, Idea Scientific Company, Minneapolis, MN) were used in inverse order, i.e., the alloy electrode being used as anode and the platinum electrode as cathode. Nitrocellulose membranes were blocked using PBS containing $10 \%(\mathrm{w} / \mathrm{v})$ low-fat milk powder and $0.3 \%$ Tween 20 , followed by incubation for $2 \mathrm{hr}$ with primary antibody in blocking medium. The primary antibodies used and their dilution and concentration were as follows: rat $\mathrm{mAb} 25 \mathrm{H} 11$, hybridoma supernatant $1: 10(\approx 2$ $\mu \mathrm{g} / \mathrm{ml}$ ); rabbit antiserum against the $\mathrm{C}$ terminus of ephrin B (Brückner et al., 1997) (anti-Lerk2A; a kind gift from Dr. R. Klein) 1:50. After washing, the nitrocellulose membranes were incubated for 45 min with secondary antibody (peroxidase-conjugated goat anti-rat or anti-rabbit, $0.5 \mu \mathrm{g} / \mathrm{ml}$ ) followed by the ECL system (Amersham Buchler, Braunschweig, Germany). Alternatively, rabbit anti-rat $\operatorname{IgG} / \operatorname{IgM}(1 \mu \mathrm{g} / \mathrm{ml}$; Dianova) was used as secondary antibody followed by $\left[{ }^{125} \mathrm{I}\right]$ Protein A $(0.12 \mu \mathrm{Ci} / \mathrm{ml}$; Amersham Buchler). In some experiments, the nitrocellulose membrane was incubated for $30 \mathrm{~min}$ at $55^{\circ} \mathrm{C}$ in PBS in the absence or presence of $10 \mathrm{~mm}$ DTT before the blocking step.

Streptavidin blotting. Streptavidin blotting was performed as described above for immunoblotting, except that nitrocellulose membranes were incubated for 45 min with peroxidase-conjugated streptavidin 1:5000 (Pierce, Rockford, IL) instead of antibodies, followed by ECL.

Immunoblot stripping. Immunoblots were incubated in $1 \%(\mathrm{w} / \mathrm{v}) \mathrm{SDS}$, $10 \mathrm{~mm}$ DTT for $20-30 \mathrm{~min}$ at $55^{\circ} \mathrm{C}$, followed by washing with blocking medium. Removal of antibody was verified by subjecting the stripped nitrocellulose membrane to ECL. Nitrocellulose membranes were then subjected to immunoblotting or streptavidin blotting as described above.

\section{Miscellaneous}

Protein was determined using a modified Lowry procedure (Markwell et al., 1978).

\section{RESULTS}

\section{mAb $25 \mathrm{H} 11$ recognizes a developmentally regulated antigen predominantly expressed in the anterolateral telencephalon}

A rat was immunized with cells dissociated from E12.5 mouse telencephalon, and several monoclonal antibodies were isolated based on the expression pattern of the corresponding antigen revealed by immunohistochemistry (Weigmann et al., 1997). Figure 1 shows the immunoperoxidase staining in the embryonic mouse brain of the antigen recognized by one $\mathrm{mAb}$, referred to as $25 \mathrm{H} 11$ (see legend to Fig. 1 for specific vs nonspecific staining). At E12.5 (Fig. 1 $A-C, F$ ), 25H11 immunoreactivity was observed in the anterior and lateral telencephalon, with strong staining in the ventricular zone. The medial telencephalon and the future ganglionic eminences (Fig. $1 B$ ) were largely unstained. In the diencephalon, weak staining was confined to a region that will give rise to the hypothalamus (Fig. $1 C$, arrow). Outside the brain, immunoreactivity was confined to mesenchymal cells (Fig. $1 A-$ $C)$, the roof plate of the spinal cord all along the anteroposterior axis, and around the dorsal root ganglia (data not shown). 
A
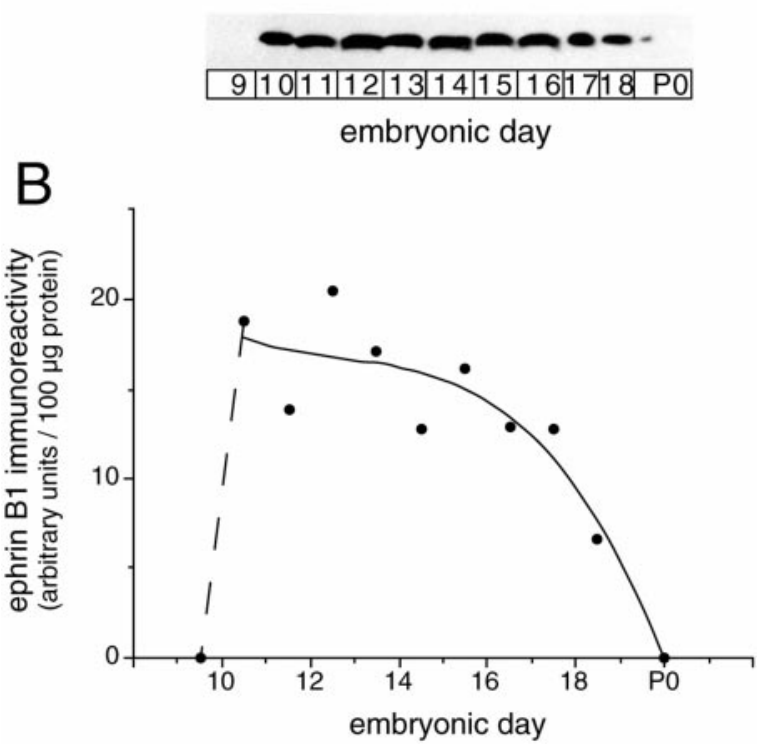

Figure 7. Time course of ephrin B1 immunoreactivity in the developing telencephalon. $A$, Ephrin B1 immunoblot (mAb 25H11) of the total homogenate $(100 \mu \mathrm{g}$ of protein) of mouse telencephalon at various developmental stages (E9.5-E18.5, labeled as E9-E18 for simplicity, and P0). B, Quantification of the immunoblot shown in $A$. The solid line is a curve fit (Cricket Graph 1.3, polynomal 3) of the values for E10.5-P0. Note the abrupt onset of ephrin B1 immunoreactivity from E9.5 to E10.5 (dashed line).

The expression of the $25 \mathrm{H} 11$ antigen in the anterolateral telencephalon was developmentally regulated (Fig. $1 D-H$ ), with the onset of expression at E10 (see also Figs. 8 and 9), persistence in the ventricular zone through E14.5 and decline thereafter. (The temporal pattern of expression of the $25 \mathrm{H} 11$ antigen is described in greater cellular detail in Fig. 8).

\section{The $25 \mathrm{H} 11$ antigen is a $47 \mathrm{kDa}$ integral membrane protein}

Immunoblotting of E13.5 mouse telencephalon using mAb 25H11 showed that the antigen has a mean apparent molecular weight of $47 \mathrm{kDa}$ under nonreducing conditions (Fig. $2 A$ ). Under reducing conditions no signal could be detected (Fig. $2 B$ ), suggesting that the epitope recognized by the mAb $25 \mathrm{H} 11$ was destroyed by reducing agents. After high-speed centrifugation of a homogenate of telencephalic vesicles, the $25 \mathrm{H} 11$ antigen was quantitatively recovered in the membrane pellet, from which it was not extracted by carbonate at pH 11 (Fig. 2C). After floatation of carbonate-treated membranes in a sucrose step gradient, the $25 \mathrm{H} 11$ antigen was recovered at the $0.5 / 1.0 \mathrm{M}$ sucrose interface (Fig. 2D). Together, these observations indicated that the 25H11antigen is tightly membrane-associated. After phase partitioning of a Triton X-114 extract of carbonate-treated membranes, the $25 \mathrm{H} 11$ antigen was recovered in the detergent phase, consistent with it being an integral membrane protein (Fig. 2E).

\section{Purification of the $25 \mathrm{H} 11$ antigen and its identification as ephrin B1}

Given its intriguing spatial and temporal pattern of expression (see also Figs. 8-10), the 25H11 antigen was purified and identified by nanosequencing. E13 telencephalon was used as source, because various adult mouse tissues were found to contain much less, if any, 25H11 immunoreactivity per protein (data not shown). The $25 \mathrm{H} 11$ antigen was purified from $\mathrm{pH} 11$-treated membranes derived from $\approx 2,500$ telencephali by immunoaffinity chromatography on mAb $25 \mathrm{H} 11$ coupled to Sepharose beads, followed by preparative SDS-PAGE (Fig. 3A). Analysis of the eluate obtained after immunoaffinity chromatography by SDSPAGE and 2D-PAGE showed that it consisted of highly purified 25H11 antigen (Fig. 3B, C, $C^{\prime}$ ).

We noticed that, in the course of purification, a variable but significant proportion of the $25 \mathrm{H} 11$ antigen was recovered, on nonreducing SDS-PAGE, as a $\approx 100 \mathrm{kDa}$ species (Fig. $4 A$, open arrow), in addition to the typical $47 \mathrm{kDa}$ form (Figs. $2 A, 4 A$, filled arrow). Re-electrophoresis of the biotinylated 100 and $47 \mathrm{kDa}$ form of the $25 \mathrm{H} 11$ antigen under nonreducing and reducing conditions followed by streptavidin blotting showed that the former was a disulfide-linked dimer of the latter (Fig. 4B).

The 25H11 antigen was unambiguously identified as ephrin B1 by nanoelectrospray tandem mass spectrometry. The sequence of four peptides obtained from the $47 \mathrm{kDa}$ form of the purified $25 \mathrm{H} 11$ antigen after tryptic digestion matched that of predicted tryptic peptides of ephrin B1 but not the other members of the ephrin B family (Fig. 5A). Two of the four peptides (peptides 3 and 4) were independently obtained from the $100 \mathrm{kDa}$ form of the purified 25H11 antigen (Fig. 5A).

The identity of the $25 \mathrm{H} 11$ antigen as ephrin B1 was corroborated by comparative immunoblotting using mAb 25H11 and an ephrin B antiserum. On immunoblotting after SDS-PAGE of the eluate obtained after immunoaffinity chromatography, the ephrin $\mathrm{B}$ antibody recognized the same 100 and $47 \mathrm{kDa}$ bands as $\mathrm{mAb}$ $25 \mathrm{H} 11$ (Fig. 5B). On immunoblotting after 2D-PAGE of pH11treated membranes from E13.5 mouse telencephalon, the same antigen as originally recognized by mAb $25 \mathrm{H} 11$ (Fig. 5C) was recognized by the ephrin $\mathrm{B}$ antibody after reprobing the filter (Fig. 5C').

\section{The pattern of expression of ephrin B1 in the embryonic telencephalon is distinct from that of ephrin B2 and ephrin B3}

On double immunofluorescence using mAb 25H11 and the ephrin $\mathrm{B}$ antiserum, virtually indistinguishable immunostaining patterns were observed in the ventricular zone and mantle zone of the E10.5 mouse telencephalon (Fig. 6A,B). The same was the case for the ventricular zone of the E14.5 telencephalon (Fig. $6 C, D$ ). However, in contrast to mAb $25 \mathrm{H} 11$ (Fig. 6C), the ephrin $\mathrm{B}$ antiserum, which was raised against a cytoplasmic peptide epitope conserved between mouse ephrins B1, B2, and B3 (Brückner et al., 1997), also stained the intermediate zone, cortical plate, and marginal zone of the E14.5 telencephalon (Fig. $6 D$ ). This is consistent with the ephrin $\mathrm{B}$ antibody recognizing not only ephrin B1 but also ephrins B2 and B3, whose mRNAs have also been shown to be expressed in these regions of the developing telencephalon (Brückner et al., 1999). In support of this conclusion, an antibody specific for ephrin B2, like the ephrin B antibody (Fig. 6D), stained the E14.5 telencephalon from the ventricular zone through the marginal zone (Fig. $6 E$ ), with the immunostaining being abolished by the presence of a peptide blocking the antibody-ephrin B2 binding (Fig. 6F). A similar pattern of immunostaining (although of lesser intensity) was observed with an antibody specific for ephrin B3 (data not shown). We conclude that mAb $25 \mathrm{H} 11$ is specific for ephrin B1. 


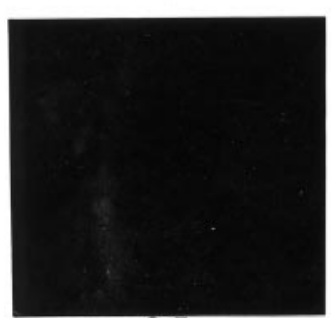

9.5

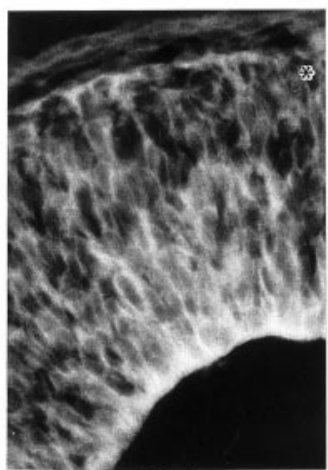

10.5

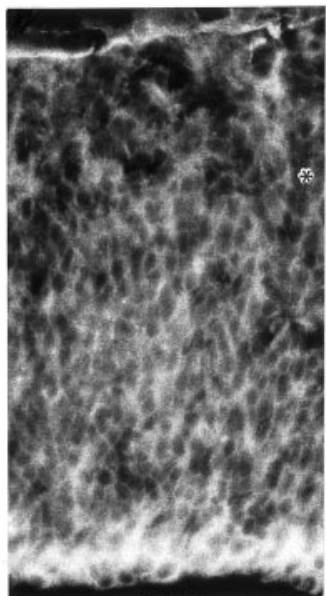

12.5

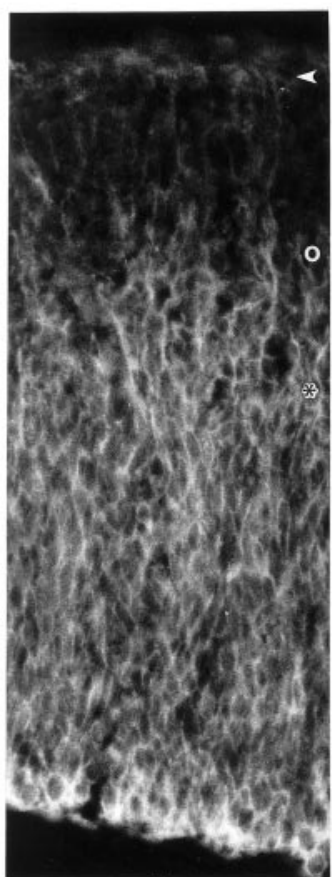

14.5

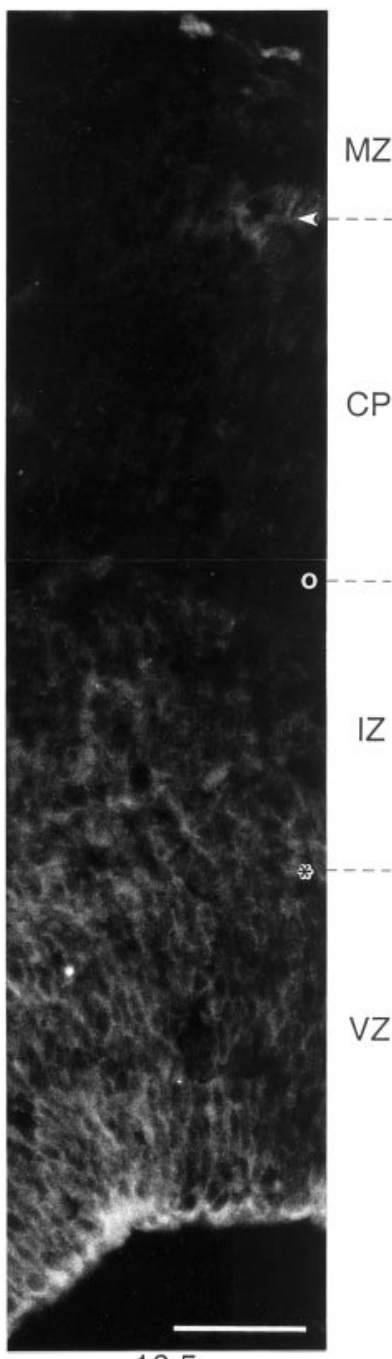

16.5

Figure 8. Pattern of expression of ephrin B1 in the developing mouse neocortex. Immunofluorescence staining for ephrin B1 (mAb 25H11) on transverse cryosections of the developing mouse neocortex at the indicated stages (embryonic days). $V Z$, Ventricular zone; $I Z$, intermediate zone; $C P$, cortical plate; $M Z$, marginal zone (E10.5, mantle zone). The ventricular side of the neuroepithelium is down; asterisks, boundary between ventricular and intermediate zones; open circles, boundary between intermediate zone and cortical plate; arrowheads, boundary between cortical plate and marginal zone. Conditions of 25H11 immunolabeling and photography at the various stages were identical. Note the appearance of ephrin B1 immunoreactivity between E9.5 and E10.5, concomitant with the onset of neurogenesis in the telencephalon. Staining is strongest in the ventricular and intermediate zone and declines during the late phase of neurogenesis. All panels are the same magnification. Scale bar, $50 \mu \mathrm{m}$.

\section{The onset of expression of ephrin B1 in the telencephalon coincides with the onset of neurogenesis}

Immunoblotting of telencephalon using mAb $25 \mathrm{H} 11$ revealed a sharp onset of expression of ephrin B1 between E9.5 and E10.5 (Fig. 7), which correlates with the onset of neurogenesis in this part of the developing mouse brain (Cochard and Paulin, 1984; Easter et al., 1993). Ephrin B1 was detected during the entire period of neurogenesis in the telencephalon (E10.5-E17), with its level decreasing at later stages when expressed per total protein (Fig. 7B), and became virtually undetectable after birth.

\section{Expression of ephrin B1 in the developing} telencephalon is strongest in the ventricular zone and the adjacent mantle/intermediate zone and displays a ventricular-high, pial-low gradient

On immunostaining of the telencephalon using mAb 25H11, ephrin B1 was detected in the ventricular zone where most, if not all, neuroepithelial cells were stained from E10.5 onwards (Fig. 8). In addition, the cell layer adjacent to the ventricular zone, i.e., the mantle zone at E10.5-E12.5 and the intermediate zone at E14.5-E16.5, was also stained (Fig. 8). Ephrin B1 staining in the cortical plate and marginal zone at E14.5-E16.5 was sparse (Fig. 8 ) and largely confined to the processes and endfeet of radial glial cells (see Fig. 10). Ephrin B1 staining in the ventricular zone became weaker after E15.5 (Fig. 8) and, consistent with the results of immunoblotting (Fig. 7), was virtually undetectable after birth (data not shown). The intensity of ephrin B1 staining was consistently highest at the ventricular side and declined toward the pial side (Fig. 8, see also Figs. $6 \mathrm{C}$ and $10 \mathrm{~A}$ below).

\section{At the onset of expression in the ventricular zone, ephrin B1-immunoreactive cells include neuron- generating neuroepithelial cells}

Double immunofluorescence revealed that at the onset of expression of ephrin B1 in the ventricular zone of the telencephalon, 
Figure 9. Coexpression of ephrin B1 and TIS21, a marker of neurongenerating neuroepithelial cells, in ventricular zone cells at the onset of neurogenesis. Double immunofluorescence of a transverse cryosection of the E10.0 mouse telencephalon, using $\mathrm{mAb} 25 \mathrm{H} 11$ against ephrin B1 followed by DTAF-conjugated secondary antibody $\left(A, A^{\prime}\right)$ and affinity-purified anti-TIS21 antibody followed by TRITC-conjugated secondary antibody $\left(B, B^{\prime}\right)$. Neuron-generating neuroepithelial cells (arrowheads), identified by TIS 21 staining $(B)$ (Iacopetti et al., 1999), express ephrin B1 $(A)$. Comparison of the staining before $(A$, $B)$ and after $\left(A^{\prime}, B^{\prime}\right)$ bleaching the fluorescein fluorescence (identical conditions of photography for $A$ and $A^{\prime}$ and for $B$ and $B^{\prime}$ ) showed that the staining attributed to ephrin B1 was abolished, whereas that attributed to TIS21 remained, confirming its authenticity. The ventricular side of the neuroepithelium is down. The spreading of the onset of neurogenesis is from left to right. Scale bar: $B^{\prime}, 20 \mu \mathrm{m}$.
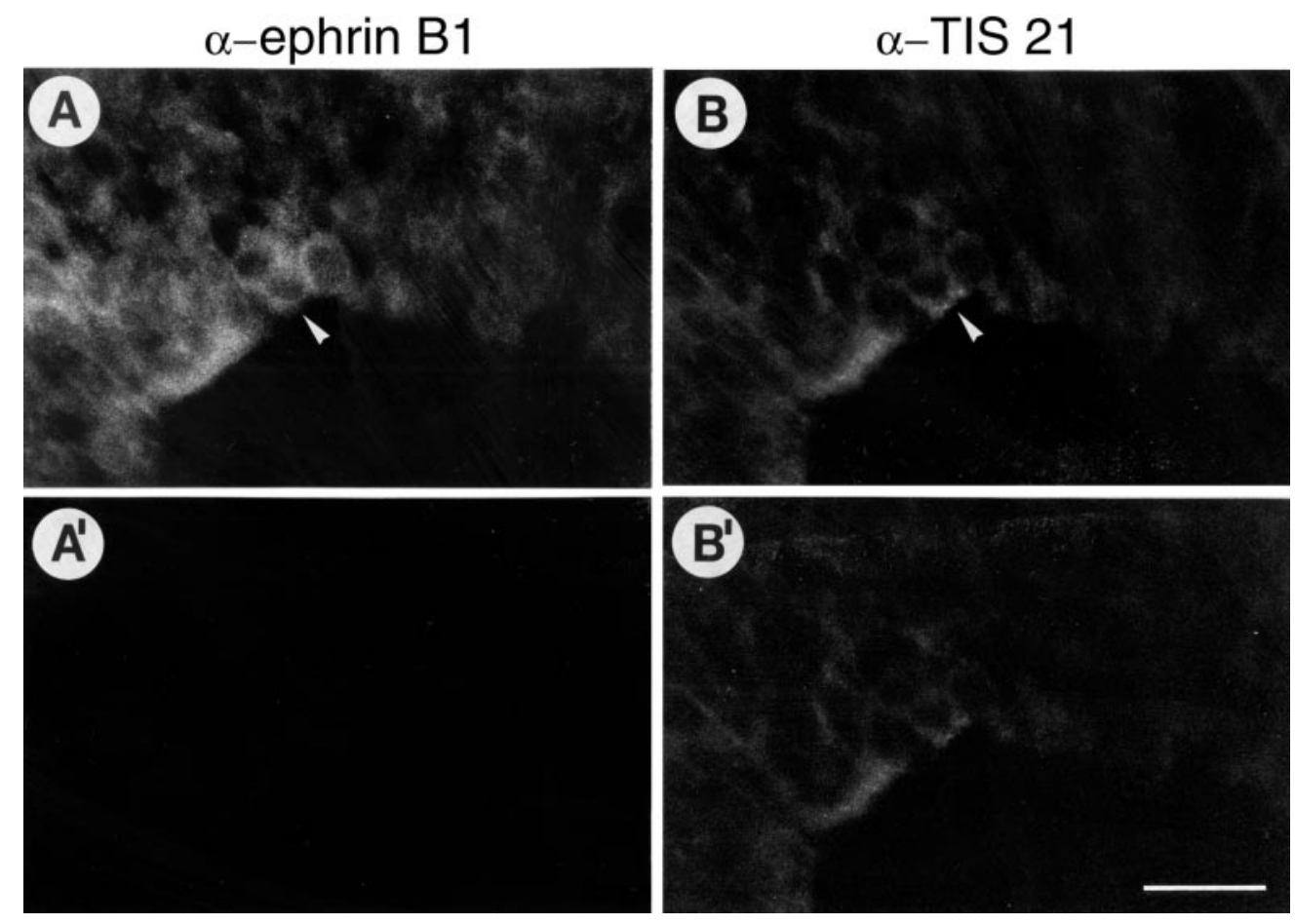

i.e., at $\approx$ E10.0, the first neuroepithelial cells immunoreactive with mAb 25H11 (Fig. 9A, arrowhead) included some that also expressed TIS21 (Fig. 9B, arrowhead), a marker of neurongenerating neuroepithelial cells (Iacopetti et al., 1999). Shortly thereafter (E10.5, E12.5), when most if not all neuroepithelial cells showed ephrin B1 immunostaining (Fig. 8), double immunofluorescence confirmed that still both TIS21-positive and TIS21-negative neuroepithelial cells expressed ephrin B1 (data not shown).

\section{Neurons in the intermediate zone express ephrin B1}

Ephrin B1 expression in the ventricular zone, as revealed by immunostaining using mAb 25H11, was not confined to neuroepithelial cells but was also detected, as shown for E14.5, in neurons migrating through the ventricular zone (Fig. 10 A, arrowhead), identified by staining for $\beta$ III-tubulin (Fig. $10 \mathrm{~B}$, arrowhead). Analysis of $\beta$ III-tubulin immunoreactivity in the other layers of the ventricular wall revealed that neurons in the intermediate zone, presumably including subplate neurons (Fig. 10B, arrows), expressed ephrin B1 (Fig. 10A, arrows), whereas those located in the cortical plate did not.

\section{Radial glial cells express ephrin B1}

Nestin is a marker of neuroepithelial cells (Lendahl et al., 1990), including radial glial cells (Hockfield and McKay, 1985), which can be regarded as a specialized type of neuroepithelial cell (Huttner and Brand, 1997). We used nestin to investigate the cell type responsible for the ephrin B1 staining observed in the cortical plate and marginal zone (Fig. 8). Double immunofluorescence at E14.5 showed that the immunostaining for ephrin B1 obtained using mAb 25H11 (Fig. 10C) was largely colocalized with that for nestin (Fig. 10D), indicating that it was associated with processes and endfeet of radial glial cells.

\section{Ephrin B1 is found on the apical as well as basolateral plasma membrane of neuroepithelial cells}

Given that ephrin B1 is a plasma membrane protein (Flanagan and Vanderhaeghen, 1998; Holder and Klein, 1999; O’Leary and
Wilkinson, 1999), the intense staining for ephrin B1 at the ventricular side of the telencephalic neuroepithelium observed on immunofluorescence using mAb 25H11 (Figs. 6C, 8, 10A) could reflect its localization on the lateral plasma membrane of the neuroepithelial cells with concentration toward the ventricle, or its localization on their apical (ventricular) plasma membrane proper. Immunogold labeling of ultrathin cryosections of E10.5 neuroepithelial cells using mAb 25H11 showed that ephrin $\mathrm{B} 1$ is indeed expressed on their apical plasma membrane (Fig. 11 $A$ ), in addition to being expressed on their lateral plasma membrane (Fig. 11B). Ephrin B1 was not detected on intracellular membranes (Fig. 11 $A, B$ ).

\section{mAb $25 \mathrm{H} 11$ recognizes an extracellular epitope on ephrin B1}

We used cell surface immunofluorescence to determine whether the epitope on ephrin B1 recognized by mAb 25H11 was extracellularly exposed. After addition of mAb $25 \mathrm{H} 11$ to intact neuroepithelial cells in E11.5 telencephalic explants followed by fluorescently labeled secondary antibody, typical cell surface staining was observed (Fig. 11C). In contrast, no staining was detected after addition of an antibody directed against the intracellular, cytoplasmic tail of prominin (Fig. 11D), a transmembrane protein present on the ventricular surface of neuroepithelial cells (Weigmann et al., 1997). However, immunostaining for prominin was observed when the latter antibody was added to fixed, detergent-permeabilized neuroepithelial cells (data not shown). We conclude that mAb 25H11 recognizes an extracellular epitope on ephrin B1.

\section{DISCUSSION}

\section{Identification of the $25 \mathrm{H} 11$ antigen as ephrin B1}

We identified the antigen recognized by the novel monoclonal antibody $25 \mathrm{H} 11$ as ephrin B1, based on the following lines of evidence. First, the sequence of several peptides obtained from the 100 and $47 \mathrm{kDa}$ forms of the purified 25H11 antigen matched that of predicted tryptic peptides of ephrin B1 but not the other 

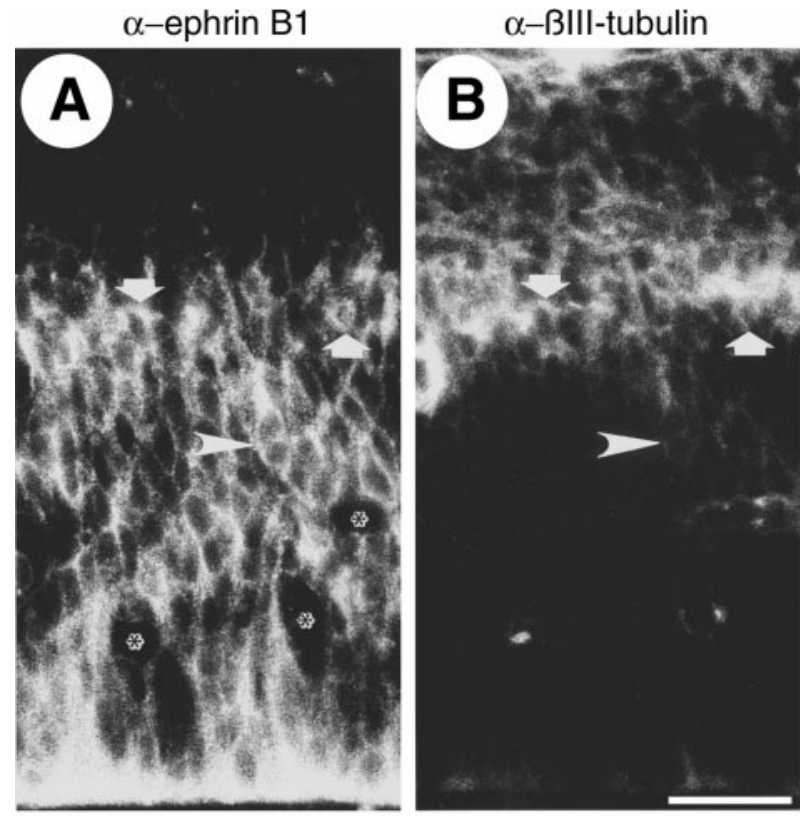

$\mathrm{CP}$
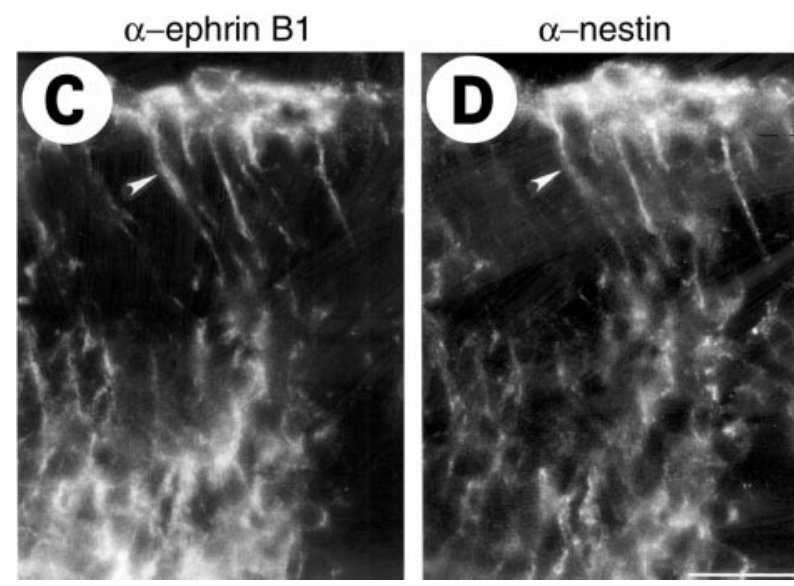

$\mathrm{MZ}$

Figure 10. Neurons in the intermediate zone and radial glial cells express ephrin B1. Double immunofluorescence for ephrin B1 (mAb 25H11) $(A)$ and $\beta$ III-tubulin $(B)$, and for ephrin B1 (mAb 25H11) $(C)$ and nestin $(D)$, of transverse cryosections of the E14.5 mouse telencephalon. $V Z$, Ventricular zone; $I Z$, intermediate zone; $C P$, cortical plate; $M Z$, marginal zone. The ventricular side of the neuroepithelium is down. In addition to ephrin B1 staining of neuroepithelial cells, which is particularly abundant on their ventricular side $(A)$, neurons in the ventricular zone (arrowheads) and intermediate zone (arrows), identified by $\beta$ III-tubulin staining $(B)$, as well as radial glial cell processes, identified by nestin staining ( $D$, arrowheads), show ephrin B1 immunoreactivity $(A, C)$. Asterisks, Blood vessels. Scale bars: $B, 50 \mu \mathrm{m} ; D, 24 \mu \mathrm{m}$.

members of the ephrin B family (Fig. $5 A$ ). Second, on immunoblotting after SDS-PAGE or 2D-PAGE, an ephrin B antiserum recognized the same 100 and $47 \mathrm{kDa}$ forms as mAb 25H11 (Fig. $\left.5 B, C, C^{\prime}\right)$. Third, on double immunofluorescence using $\mathrm{mAb}$ $25 \mathrm{H} 11$ and the ephrin B antiserum, virtually indistinguishable immunostaining patterns were observed in the ventricular zone of the E10.5 and E14.5 telencephalon (Fig. $6 A-D$ ). The observation that the ephrin $\mathrm{B}$ antiserum, in contrast to $\mathrm{mAb} 25 \mathrm{H} 11$, also broadly stained the intermediate zone, cortical plate, and marginal zone of the E14.5 telencephalon (Fig. $6 C, D$ ) is explained by the former antibody recognizing not only ephrin B1 but also ephrins B2 and B3 (Brückner et al., 1997), which are present in these regions (Fig. $6 E$; data not shown), consistent with the expression of their mRNAs in the telencephalon at this developmental stage (Brückner et al., 1999).

In addition, the following observations are consistent with the identification of the $25 \mathrm{H} 11$ antigen as ephrin B1. The 25H11 antigen had an apparent molecular weight of $47 \mathrm{kDa}$ (Fig. $2 \mathrm{~A}$ ), in line with the molecular weight of the authentic ephrin B1 glycoprotein (Shao et al., 1994; Bouillet et al., 1995). The 25H11 antigen behaved like an integral membrane protein (Fig. $2 C-E$ ), consistent with ephrin B1 being transmembraneous (Flanagan and Vanderhaeghen, 1998; Holder and Klein, 1999; O'Leary and Wilkinson, 1999). And finally, the 25H11 antigen was specifically observed at the cell surface (Fig. 11), in line with the localization of ephrin B1 at the plasma membrane (Flanagan and Vanderhaeghen, 1998; Holder and Klein, 1999; O’Leary and Wilkinson, 1999).

The $100 \mathrm{kDa}$ form of ephrin B1 represented a homodimer covalently linked by a disulfide bond (Fig. 4). These covalent homodimers, which were generated in the course of the immunoaffinity isolation and nonreducing SDS-PAGE analysis of the $25 \mathrm{H} 11$ antigen, were particularly abundant when the Triton X-100 lysate of membranes was directly, i.e., without previous centrifugation to obtain a Triton X-100 extract, incubated with 25H11Sepharose (Fig. 4A). Because ephrin B1 has been reported to be partially recovered in Triton X-100-insoluble complexes (Brückner et al., 1999) and contains a single cysteine residue in its transmembrane domain (Shao et al., 1994; Bouillet et al., 1995), it is conceivable that the covalent homodimerization reflects the antibody-induced dimerization of ephrin B1 followed by disulfide bond formation in the plane of the detergent-insoluble membrane microdomain under the oxidizing conditions of analysis.

The temporal and spatial expression patterns of ephrin B1 observed in this study are consistent with in situ hybridization data for ephrin B1 mRNA (Bouillet et al., 1995; Flenniken et al., 1996; Brückner et al., 1999) and with whole-mount stainings to detect binding sites for the ectodomains of Eph-B receptors (Flenniken et al., 1996; Gale et al., 1996). This suggests that the temporal and spatial expression patterns obtained with the mAb $25 \mathrm{H} 11$ reflect those of ephrin B1 as such, rather than an epitope on the ephrin B1 molecule whose expression is subject to regulation.

\section{Possible roles of ephrin B1 in the ventricular zone}

What might be the physiological role of ephrin B1 in the developing telencephalon? The key observations in considering this question are (1) the rapid appearance of ephrin B1 at the onset of neocortical neurogenesis (Figs. 7-9), (2) its persistence through the period of neurogenesis (Figs. $1 D-H, 7,8)$, (3) its expression predominantly in the ventricular zone (Figs. $1,6 C, 8,10 A$ ), and (4) its presence in virtually all neuroepithelial cells within the immunoreactive regions of the telencephalic ventricular zone (Figs. 6C, 8, 10A). These observations suggest that the role of ephrin B1 in the developing telencephalon is somehow related to neocortical neurogenesis. Whereas the specific role of ephrin B1 in the developing telencephalon remains to be elucidated, the paradigms of ephrin B function revealed by the study of other morphogenetic processes, specifically ephrin $\mathrm{B} \leftrightarrow$ Eph B receptor bidirectional signaling (Drescher et al., 1997; Flanagan and Vanderhaeghen, 1998; Holland et al., 1998; Holder and Klein, 1999; O’Leary and Wilkinson, 1999) suggest several interesting possibilities.

First, ephrin B1 may be involved in a signaling process between neuroepithelial cells. Because ephrin B1 is induced in virtually all 


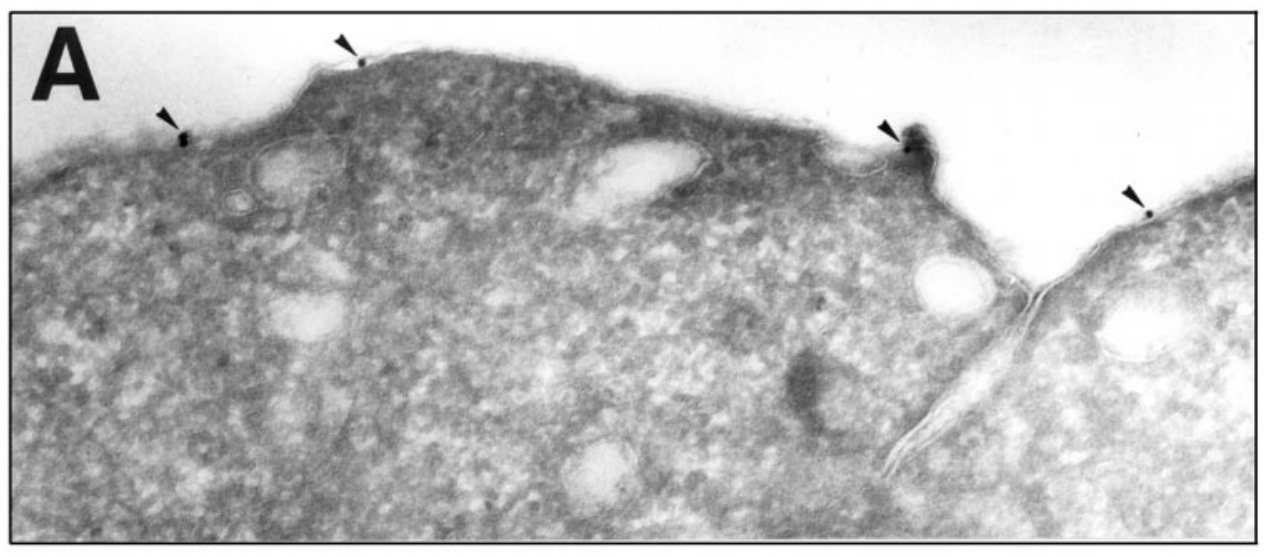

Figure 11. Localization of ephrin B1 on the apical and lateral plasma membrane of neuroepithelial cells. $A, B$, Ultrathin cryosections were stained for ephrin $\mathrm{B} 1(\mathrm{mAb}$ 25H11) followed by $14 \mathrm{~nm}(A)$ and $9 \mathrm{~nm}$ $(B)$ protein A-gold. Shown is the apical (ventricular) $(A)$ and lateral $(B)$ membrane of E10.5 neuroepithelial cells. Note that the immunoreactivity is confined to the plasma membrane (arrowheads). No signal is observed in the nucleus $(N)$ or over membranes in the cytoplasm. No labeling was observed when mAb $25 \mathrm{H} 11$ was omitted in the immunogold labeling procedure or when cell types lacking $25 \mathrm{H} 11$ immunofluorescence signal were examined by immunogold labeling. Both panels are the same magnification. Scale bar, $200 \mathrm{~nm}$. $C, D, \mathrm{mAb}$ $25 \mathrm{H} 11$ recognizes an extracellular epitope on ephrin B1. Isolated E11.5 mouse telencephalic vesicles were incubated at $4^{\circ} \mathrm{C}$ with either mAb $25 \mathrm{H} 11(C)$ or the rabbit antiserum against the intracellular, cytoplasmic tail of prominin $(D)$, a plasma membrane protein found on the ventricular surface of neuroepithelial cells (Weigmann et al., 1997), followed by appropriate secondary antibody, fixation and preparation of cryosections. Note the cell surface immunofluorescence for ephrin B1.
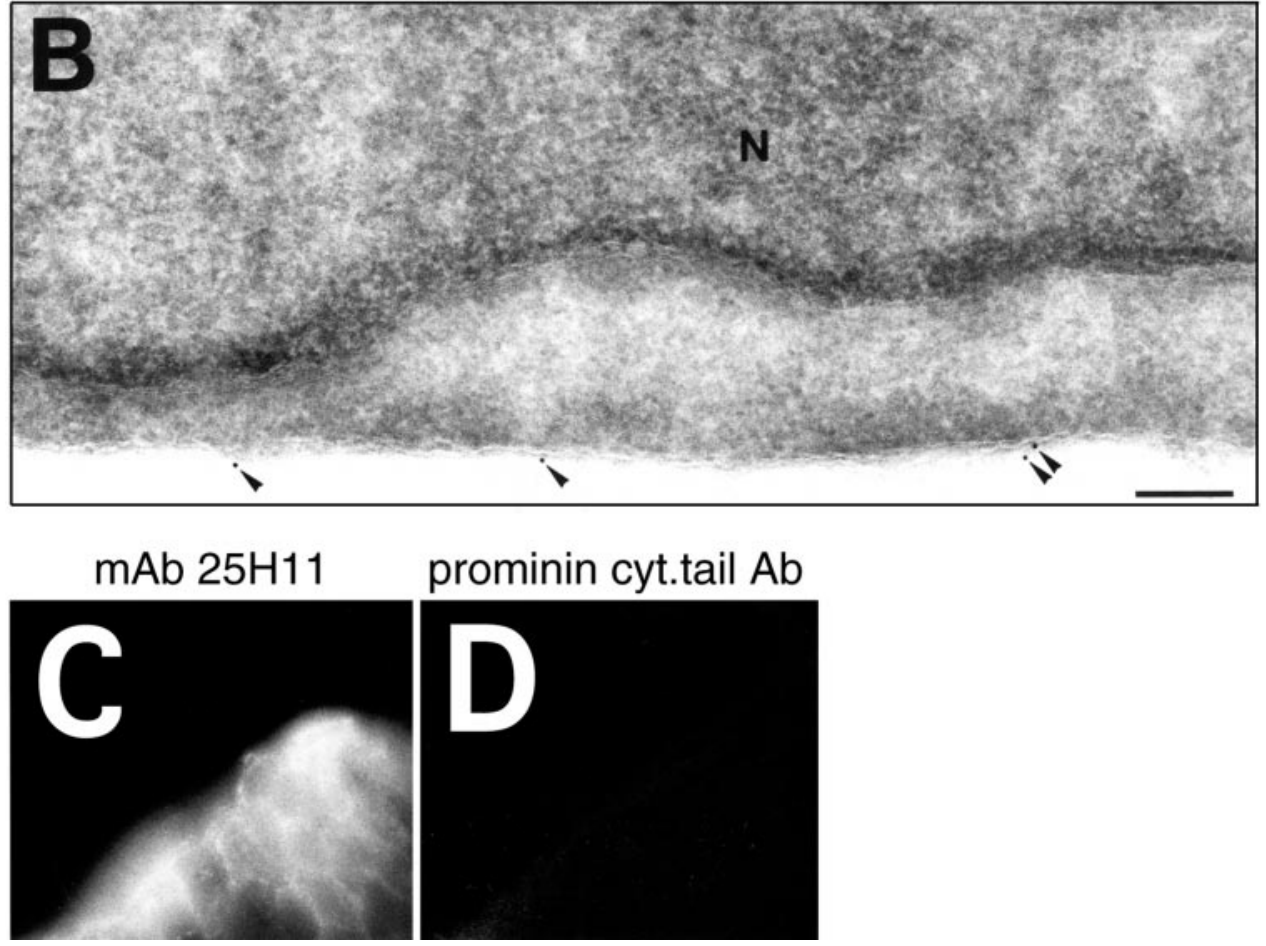

neuroepithelial cells at the onset of neurogenesis, it cannot be the factor that provides the cellular specificity in the switch of individual neuroepithelial cells from proliferative to neurongenerating division, which initially occurs in very few neuroepithelial cells only (Smart, 1972a; Cochard and Paulin, 1984; Easter et al., 1993; Iacopetti et al., 1999). However, ephrin B1 may prime neuroepithelial cells to become receptive to switch to neurogenesis, or it may trigger neurogenesis provided that the Eph receptor to which it binds is selectively expressed in those neuroepithelial cells that switch to neurogenesis. In either case, the intercellular signaling involving ephrin B1 would have a role in cell fate determination, for which however there is no precedent as far as we are aware.

Second, ephrin B1 may be expressed in the ventricular zone to protect it from one of the consequences of neurogenesis, i.e., the potential growth of axons into the ventricular zone. Ephrin-Eph receptor signaling, including that involving ephrin Bs (Henkemeyer et al., 1996), can lead to growth cone collapse, as part of the complex process of axon guidance (Drescher et al., 1997; Flanagan and Vanderhaeghen, 1998; Holland et al., 1998; Holder and Klein, 1999; O’Leary and Wilkinson, 1999). Consistent with this possibility, expression of ephrin B1 was detected in neurons in the intermediate zone (Fig. 10 A), but not in neurons that had arrived in the cortical plate (Figs. 8, 10), i.e., those engaged in axogenesis.

Third, ephrin B1 may be involved in a signaling process between neuroepithelial cells and neurons that leads to the migration of neurons out of the ventricular zone. Ephrin-Eph receptor signaling, including that involving ephrin B1, has been shown to have a role in cell migration (Krull et al., 1997; Wang and Anderson, 1997; for review see Flanagan and Vanderhaeghen, 1998; Holder and Klein, 1999; O'Leary and Wilkinson, 1999). It is interesting to note that the intensity of ephrin B1 immunoreactivity along the lateral plasma membrane of neuroepithelial cells consistently showed a ventricular-high, pial-low gradient (Figs. 6C, 8, 10A). If one assumes that the newborn neuron is repelled by the neuroepithelial cell surface via ephrin B1 signaling, the ephrin B1 gradient on the neuroepithelial cell surface would provide directionality of neuronal migration through the ventricular zone in the pial direction. A role of ephrin B1 in the migration of newborn neurons out of the ventricular zone would, perhaps, provide the most compelling explanation as to why ephrin B1 is predominantly expressed in those regions of the neural tube that generate the most neurons and 
hence have the greatest need for clearing them from their site of birth, i.e., the telencephalic ventricular zone producing the neurons of the neocortex.

\section{REFERENCES}

Aaku-Saraste E, Hellwig A, Huttner WB (1996) Loss of occludin and functional tight junctions, but not $\mathrm{ZO}-1$, during neural tube closureremodeling of the neuroepithelium prior to neurogenesis. Dev Biol 180:664-679.

Aaku-Saraste E, Oback B, Hellwig A, Huttner WB (1997) Neuroepithelial cells downregulate their plasma membrane polarity prior to neural tube closure and neurogenesis. Mech Dev 69:71-81.

Artavanis-Tsakonas S, Rand MD, Lake RJ (1999) Notch signaling: cell fate control and signal integration in development. Science 284: $770-776$.

Bayer SA, Altman J (1991) Neocortical development. New York: Raven.

Bordier C (1981) Phase separation of integral membrane proteins in Triton X-114 solution. J Biol Chem 256:1604-1607.

Bouillet P, Oulad-Abdelghani M, Vicaire S, Garnier J-M, Schuhbaur B, Dollé P, Chambon P (1995) Efficient cloning of cDNAs of retinoic acid-responsive genes in P19 embryonal carcinoma cells and characterization of a novel mouse gene, Stra1 (mouse LERK-2/EpIg2). Dev Biol 170:420-433.

Brückner K, Pasquale EB, Klein R (1997) Tyrosine phosphorylation of transmembrane ligands for Eph receptors. Science 275:1640-1643.

Brückner K, Pablo Labrador J, Scheiffele P, Herb A, Seeburg PH, Klein R (1999) EphrinB ligands recruit GRIP family PDZ adaptor proteins into raft membrane microdomains. Neuron 22:511-524.

Cameron HA, Hazel TG, McKay RD (1998) Regulation of neurogenesis by growth factors and neurotransmitters. J Neurobiol 36:287-306.

Campos-Ortega JA (1995) Genetic mechanisms of early neurogenesis in Drosophila melanogaster. Mol Neurobiol 10:75-89.

Caviness Jr VS, Takahashi T, Nowakowski RS (2000) Neuronogenesis and the early events of neocortical histogenesis. In: Results and problems in cell differentiation, Vol 30, Mouse brain development (Goffinet AM, Rakic P, eds), pp 107-143. Heidelberg: Springer.

Cochard P, Paulin D (1984) Initial expression of neurofilaments and vimentin in the central and peripheral nervous system of the mouse embryo in vivo. J Neurosci 4:2080-2094.

Drescher U, Bonhoeffer F, Müller BK (1997) The Eph family in retinal axon guidance. Curr Opin Neurobiol 7:75-80.

Easter SS, Ross LS, Frankfurter A (1993) Initial tract formation in the mouse brain. J Neurosci 13:285-299.

Flanagan JG, Vanderhaeghen P (1998) The ephrins and Eph receptors in neural development. Annu Rev Neurobiol 21:309-345.

Flenniken AM, Gale NW, Yancopoulos GD, Wilkinson D (1996) Distinct and overlapping expression patterns of ligands for eph-related receptor tyrosine kinases during mouse embryogenesis. Dev Biol 179:382-401.

Gale NW, Holland SJ, Valenzuela DM, Flenniken AM, Pan L, Ryan TE, Henkemeyer M, Strebhardt K, Hirai H, Wilkinson DG, Pawson T, Davis S, Yancopoulos GD (1996) Eph-receptors and ligands comprise two major specificity subclasses and are reciprocally compartmentalized during embryogenesis. Neuron 17:9-19.

Henkemeyer M, Orioli D, Henderson JT, Saxton TM, Roder J, Pawson T, Klein R (1996) Nuk controls pathfinding of commissural axons in the mammalian central nervous system. Cell 86:35-46.

Hockfield S, McKay RD (1985) Identification of major cell classes in the developing mammalian nervous system. J Neurosci 5:3310-3328.
Holder N, Klein R (1999) Eph receptors and ephrins: effectors of morphogenesis. Development 126:2033-2044.

Holland SJ, Peles E, Pawson T, Schlessinger J (1998) Cell-contactdependent signalling in axon growth and guidance: Eph receptor tyrosine kinases and receptor protein tyrosine phosphatase beta. Curr Opin Neurobiol 8:117-127.

Huttner WB, Brand M (1997) Asymmetric division and polarity of neuroepithelial cells. Curr Opin Neurobiol 7:29-39.

Iacopetti P, Michelini M, Stuckmann I, Oback B, Aaku-Saraste E, Huttner WB (1999) Expression of the antiproliferative gene TIS21 at the onset of neurogenesis identifies single neuroepithelial cells that switch from proliferative to neuron-generating division. Proc Natl Acad Sci USA 96:4639-4644.

Jacobson M (1991) Developmental neurobiology, Ed 3. New York: Plenum.

Krull CE, Lansford R, Gale NW, Collazo A, Marcelle C, Yancopoulos GD, Fraser SE, Bronner-Fraser M (1997) Interactions of Eph-related receptors and ligands confer rostrocaudal pattern to trunk neural crest migration. Curr Biol 7:571-580.

Lendahl U, Zimmerman LB, McKay RGB (1990) CNS stem cells express a new class of intermediate filament protein. Cell 60:585-595.

Mann M, Wilm M (1994) Error tolerant identification of peptides in sequence databases by peptide sequence tags. Anal Chem 66: $4390-4399$.

Markwell MAK, Haas SM, Bieber LL, Tolbert NE (1978) A modification of the Lowry procedure to simplify protein determination in membrane and lipoprotein samples. Anal Biochem 87:206-210.

McConnell SK (1995) Constructing the cerebral cortex: neurogenesis and fate determination. Neuron 15:761-768.

O'Leary DD, Wilkinson DG (1999) Eph receptors and ephrins in neural development. Curr Opin Neurobiol 9:65-73.

Rakic P (1995) Radial versus tangential migration of neuronal clones in the developing cerebral cortex. Proc Natl Acad Sci USA 92: $11323-11327$.

Shao H, Lou L, Pandey A, Pasquale EB, Dixit VM (1994) cDNA cloning and characterization of a ligand for the Cek5 receptor protein-tyrosine kinase. J Biol Chem 269:26606-26609.

Shevchenko A, Wilm M, Vorm O, Mann M (1996) Mass spectrometric sequencing of proteins from silver stained polyacrylamide gels. Anal Chem 68:850-858.

Smart IHM (1972a) Proliferative characteristics of the ependymal layer during the early development of the spinal cord in the mouse. J Anat 111:365-380.

Temple S, Qian X (1995) bFGF, neurotrophins, and the control of cortical neurogenesis. Neuron 15:249-252.

Theiler K (1989) The house mouse. Atlas of embryonic development. Heidelberg: Springer.

Wang HU, Anderson DJ (1997) Eph family transmembrane ligands can mediate repulsive guidance of trunk neural crest migration and motor axon outgrowth. Neuron 18:383-396.

Weigmann A, Corbeil D, Hellwig A, Huttner WB (1997) Prominin, a novel microvilli-specific polytopic membrane protein of the apical surface of epithelial cells, is targeted to plasmalemmal protrusions of non-epithelial cells. Proc Natl Acad Sci USA 94:12425-12430.

Wilm M, Neubauer G, Mann M (1996a) Parent ion scans of unseparated peptide mixtures. Anal Chem 68:527-533.

Wilm M, Shevchenko A, Houthaeve T, Breit S, Schweigerer L, Fotsis T, Mann M (1996b) Femtomole sequencing of proteins from polyacrylamide gels by nanoelectrospray mass spectrometry. Nature 379:466469. 